\title{
Sand spit dynamics in a large tidal- range environment: Insight from multiple LiDAR, UAV and hydrodynamic measurements on multiple spit hook development, breaching, reconstruction, and shoreline changes
}

\author{
Robin Nicolas ${ }^{1,{ }^{*}}$, Levoy Franck ${ }^{2}$, Anthony Edward J. ${ }^{3,4}$, Monfort Olivier ${ }^{2}$
}

${ }^{1}$ CEFREM Université de Perpignan Via Domitia 52 Avenue Paul Alduy Perpignan 66000, France

2 Université de Caen Normandie-CREC-54 rue du Docteur Charcot Luc sur Mer BP 49-14530, France

${ }^{3}$ CNRS, IRD, INRA, Coll France, CEREGEAix Marseille University Aix-en-Provence, France

${ }^{4}$ CNRS, UG, IFREMER, LEEISA USR 3456Centre de Recherche de Montabo Cayenne

Guyane ,Française France

* Corresponding author : Nicolas Robin, email address : nicolas.robin@univ-perp.fr

\begin{abstract}
:
Sand spits with distal hooks have been well documented from coasts with low to moderate tidal ranges, unlike high tidal-range environments. Datasets from 15 LiDAR and 3 UAV surveys between 2009 and 2019 on the Agon spit in Normandy (France), a setting with one of the largest tidal ranges in the world (mean spring tidal range: $11 \mathrm{~m}$ ), combined with in-situ hydrodynamic records between 2013 and 2017, highlight a three-stage pattern of spit hook evolution. Stage 1 (2009-2013) commenced with the onshore migration and attachment of a swash bar, followed by persistent spit accretion updrift of the bar and erosion downdrift because of the slow speed of bar migration in this large tidal-range environment. In stage 2 (2013-2016), three overwash events and a $220 \mathrm{~m}$-wide breach culminating in the total destruction of the spit during winter 2015-2016 involved the landward mobilization of thousands of cubic metres of sand. These events occurred during short durations (a few hours) when spring high tides coincided with relatively energetic waves, underscoring the importance of storms in rapid spit morphological change. Strong spring tidal currents maintained the breach. Stage 3 (2016-2019) has involved new hook construction through welding of a swash bar and spit longshore extension, highlighting the resilience of the spit over the 10-year period, and involving a positive sediment balance of $244000 \mathrm{~m} 3$. The three stages bring out, by virtue of the temporal density of LiDAR and UAV data used, a high detail of spit evolution relative to earlier studies in this macrotidal setting. The large tidal range strongly modulates the role of waves and wave-generated longshore currents, the main process drivers of spit evolution, by favouring long periods of inertia in the course of the spring-neap tidal cycle, but also brief episodes of significant morphological change when storm waves coincide with spring high tides.
\end{abstract}

Keywords : spit hook, swash bar, macrotidal inlet, longshore transport, spit breaching, overwash hotspot 


\section{Introduction}

The study of spits dates back to the end of 19th century (Gilbert, 1890) and more particularly the second half of $20^{\text {th }}$ century (Evans, 1942; Zenkovitch, 1967; Schwartz, 1972). Evans (1942) defined a spit as a type of barrier forming a kilometre-long narrow and elongated sand body, attached to a land mass at one end and terminating in open water at the other. Spits strongly depend on a longshore supply of sand, gravel or mixed sediments. Sand spits have a worldwide distribution and are found at all latitudes and on all continents. Their abundance has led to the recognition of a large range of types (Guilcher, 1954; Zenkovitch, 1967; Hallégouët, 1981; Ruz, 1989; Héquette and Ruz, 1991; Fox et al., 1995; Sanderson and Eliot, 1996; Randazzo et al., 2015; Escudero et al., 2019; Kosyan and Krylenko, 2019) from linear, recurved (with or without hooks), concave or convex plan-view shapes, to more complex shapes. Morphological differences are the result of numerous controlling factors that can interact and influence spit development processes at various timescales. Among these factors are hydrodynamic context and conditions such as waves (Allard et al., 2008; Ashton et al., 2016), tidal range and prism (Powell et al., 2006; Robin et al., 2007), inlet discharge and migration (Chaumillon et al., 2014; Adams et al., 2015), and storm-induced breaching (Sanchez-Arcilla and Jimenez, 1994, Zainescu et al., 2019), 
as well as sediment availability (Héquette and Ruz, 1991; Firth et al., 1995), sea-level rise (van de Plassche and van Heteren, 1997; Billy et al., 2018a), and geological processes and framework (Riggs et al., 1995; Billy et al., 2018b; Cooper et al., 2018). In the last few decades, anthropogenic impacts have assumed increasing importance (Garel et al., 2014; Miselis and Lorenzo-Trueba, 2017; Sadio et al., 2017; Kombiadou et al., 2019a), especially in terms of sediment budget applications and engineering interventions (Psuty et al., 2014; Stéphan et al., 2018).

The study of sand spits in a tidal-inlet context is of interest from various points of view. Spits are important from both economic (protection of port and marina accesses, sand stocks...) and environmental standpoints (bird and turtle nesting, biodiversity...). In addition, tidal inlets and their associated spits can influence the morphodynamic behavior and sediment budgets of adjacent shorelines over several kilometres (Fitzgerald, 1984, 1988; Fenster and Dolan, 1996; Hicks et al., 1999; Elias et al., 2002; Hein et al., 2019). Knowledge of spit dynamics is important, thus, in the elaboration and implementation of appropriate coastal management initiatives. Yet, maintaining their integrity in a context of overall waning of sediment supply and rising sea level will be more and more of a challenge in the $21^{\text {st }}$ century (Randazzo et al., 2015).

The distal ends of recurved spits may exhibit two or more individual hooks. The morphodynamic behaviour of such hooked spits remains a rather elusive subject (Carter, 1988; van Rijn, 1998; Ashton et al., 2016). The formation and evolution of these hooks are purportedly explained by various hypotheses among which there is no real consensus, a large range of dominant processes being invoked, depending on the physical and morphological setting of each field site. The only point of agreement 
seems to be the existence of a sedimentary platform prior to the formation of a new hook (Meistrell, 1966; Galichon, 1984; Nielsen et al., 1988). The main hypotheses are the following: (1) lengthening and rotation of the distal part of the spit following a change of direction of the main incident waves during storms (Zenkovitch, 1959; King and McCullagh, 1971; Ollerhead and Davidson-Arnott, 1995; van Rijn, 1998). Once this hook is in equilibrium with the new wave-energy conditions, its orientation stabilizes. If the angle between the coastline and the wave crests is greater than $50^{\circ}$, a new hook may develop from this point (Galichon, 1984; Ashton et al., 2001; Murray et al., 2001); (2) wave refraction around the end of the spit is frequently invoked as the main reason for distal pivoting and hook formation (Evans, 1942; Carter, 1988; van Rijn, 1998, van Heteren et al., 2006). The wave angle along the spit increases towards the distal part and leads to an increase in sediment transport to the 'fulcrum point' where such transport reaches a maximum (Ashton et al., 2016). At the same time, the wave height decreases due to refraction (Carter, 1988). As it develops, the hook extends towards a zone of lower energy where sediment transport decreases, causing cessation of hook elongation; (3) longshore transport variations (modulated by wave height) at seasonal to inter-annual timescales (Allard et al., 2008; Petersen et al., 2008; Nahon et al., 2019). Energetic swells seem to cause massive sand accumulation and spit elongation whereas less energetic swells appear to be responsible for minor accumulation and spit curvature. Longshore transport variation can also be induced by the radius of spit curvature (a proxy for the separation of tidal flows) (Hopkins et al., 2017). As the radius of curvature decreases (as the corner sharpens), the asymmetry of nearshore tidal currents is enhanced, leading to more sediment transport towards the end of the spit; (4) the influence of the migration of ebb-delta swash bars, first highlighted by King (1970). During their migration, these forms can amalgamate to 
create large, complex bars that weld onto the upper beach (Hine, 1975, 1979; Aubrey and Speer, 1984; FitzGerald, 1984, 1988; Kana et al., 1999; FitzGerald et al. 1984, 2000; Borrelli and Wells, 2003; Lindhorst et al., 2008; Pellerin Le bas and Levoy, 2018). They then form the main body of a new hook, resulting in an extension of the spit and in potential coastline accretion of several hundred metres. A variety of this hypothesis involves swash-bar influence on longshore sand transport. The proximity of the bar to the shoreline interferes with the longshore sediment transport, inducing shoreline erosion downdrift of the bar. Finally, the new shoreline orientation leads to a new hook wherein the bar does not source the main hook body but generates the process that builds this new feature (Robin and Levoy, 2007; Costas and FitzGerald, 2011). These various hypotheses have been proposed primarily for microtidal and mesotidal environments. The formation and dynamics of spit hooks in relation to the specific field characteristics of environments with large tidal ranges remain poorly documented.

The study of spits is usually carried out from maps, aerial photographs and satellite images and/or using topo-bathymetric transects. These data-source choices are driven by the large size of these sedimentary landforms and their commonly multiyear (decadal) evolution time frame. Although these data sources can provide a significant amount of information on spit behaviour, they address mainly 2D, rarely 3D changes, and commonly involve gaps of several years, thus, limiting the quantification of sedimentary changes occurring at much shorter intervals. The aim of this paper is to investigate the morphodynamics of a hooked spit (the Agon spit, France, (Fig. 1)) in a large tidal-range environment over one decade, based on seasonal 3D airborne topographic surveys. The first objective is to specify the relationship between 
breaching and formation of a hook using a combination of high-frequency Lidar and UAV surveys and hydrodynamic measurements. One particular area of attention is that of attempting to quantify the morphological evolution and the sedimentary exchanges occurring in the course of various tide and wave conditions. The second objective is to improve the spit change model proposed by Robin and Levoy (2007) for a large tidal-range setting by fitting it to a decadal timescale that integrates variability induced by seasonal wave and sediment transport conditions.

\section{Study area}

\subsection{Regnéville inlet}

The study was conducted at Regnéville inlet, on the west Cotentin coast in Normandy (France) bounding the Channel Islands embayment (Fig. 1). The west coast of Cotentin is indented by eight small inlets. The study site covers the largest of these, Regnéville inlet, which is characterized to the north by a complex spit, the Agon spit (Fig. 2). The tidal range along the spit attains $11 \mathrm{~m}$ at mean spring tides and $14 \mathrm{~m}$ during exceptional spring tides, conditions initially referred to as megatidal by Levoy et al. (2000). These tidal conditions generate a mean tidal prism in the Regnéville basin of $15 \times 10^{6} \mathrm{~m}^{3}$ per mean tidal cycle and reaching $46 \times 10^{6} \mathrm{~m}^{3}$ during spring tides. The average freshwater discharge only corresponds to $0.2 \%$ of the mean spring tidal prism $\left(10^{5} \mathrm{~m}^{3}\right.$ ) (Robin et al., 2007). The tidal currents are parallel to the spit during most of the tidal cycle due to a strong longshore gradient in water level between the Cotentin embayment and the English Channel (Levoy et al., 2001). On the mid-part of the large ebb delta of the inlet, currents are maximum at spring high tide $(0.7 \mathrm{~m} / \mathrm{s})$. 
Neap tide currents are generally weaker (mean values of $0.1 \mathrm{~m} / \mathrm{s}$ and $0.3 \mathrm{~m} / \mathrm{s}$ at low and high water respectively) (Robin et al., 2009a).

Open to the W, the Channel Islands embayment is exposed to North Atlantic Ocean waves. However, wave propagation is complicated due to the irregular shelf bathymetry, which results in decreasing wave heights on the shoreface (Levoy, 1994). Near the coast, numerous rocky platforms and the ebb tidal deltas of the various inlets modify the wave propagation patterns. The embayment may be viewed as a very large dissipative zone. $65 \%$ of recorded offshore wave heights at Les Nattes (Fig.1) are less than $0.5 \mathrm{~m}$. Wave heights larger than $1.5 \mathrm{~m}$ are observed only $2 \%$ of the time. The wave height returns over periods of 10 and 5 years are $2.25 \mathrm{~m}$ and $2.12 \mathrm{~m}$, respectively. The waves are essentially from a W quadrant (waves with SW to NW $\left(230^{\circ}-310^{\circ}\right)$ directions represent more than $90 \%$ of the observations) in response to the prevailing synoptic winds in this region. The peak periods range from 4 to $6 \mathrm{~s}$. The local wave regime also comprises rare North Atlantic swells with periods ranging from 8 to $12 \mathrm{~s}$.

The Agon spit migrates to the $S$ and its distal end exhibits eight recurves consistent with the dominant wave direction and southerly longshore sediment transport (Robin et al., 2007; Robin et al., 2009a) estimated at about 40,000 $\mathrm{m}^{3} \mathrm{yr}^{-1}$ (Levoy, 1994). This transport is only significant around high tide, when wave heights are much less attenuated as a result of the greater depths, and only during moderate to strong wave conditions (Levoy et al., 2000). The Regnéville ebb delta is a large, asymmetrically shaped sand body covering an area of over $11 \mathrm{~km}^{2}$. The exposed zone at low tide extends more than $4 \mathrm{~km}$ offshore. The sandy beach updrift of the inlet can be up to 1 
$\mathrm{km}$ wide at low tide, and typically exhibits a concave shape that evolves into a flat lowtide zone (Levoy et al., 2001). Tidal fluctuations lead to a morphodynamic segmentation of the beach profile with the following elevations: the foreshore $>6.49$ m IGN 69 (MHWS), the high-tide zone between 6.49 m IGN 69 (MHWS) and $3.49 \mathrm{~m}$ IGN 69 (MHWN), the mid-tide zone between 3.49 m IGN 69 (MHWN) and -1,79 m IGN 69 (MLWN) and the low-tide zone between -1,79 m IGN 69 (MLWN) and -4.66 m IGN 69 (MLWS) (Robin, 2007) (Fig. 3).

Numerous swash and transverse bars occur on the updrift coast of the ebb delta, but these features are absent on the southern downdrift side which is characterized mainly by a flat topography and, close to the channel, by a bar parallel to the channel meander (Fig. 2). Swash bars are generally small (2 m high and $250 \mathrm{~m}$ long) compared with those in lower tidal-range environments (Robin et al., 2007). They occur in the mid-tidal zone and are transverse to the shoreline with an angle of about $40^{\circ}$. These bars move onshore under surf-zone processes and Hs> $0.7 \mathrm{~m}$ (Robin et al., 2009a). Transverse bars are larger with lengths varying from $320 \mathrm{~m}$ to $1300 \mathrm{~m}$ and mean heights comprised between $0.5 \mathrm{~m}$ and $2.5 \mathrm{~m}$. They are subject to migration towards the north, under the influence of the strong shore-parallel spring tidal currents that flow northwards during most of the tidal cycle (Levoy et al., 2013; Montreuil et al., 2014). This migration direction is opposite to that of wave-induced longshore drift on this coast. 


\subsection{Formation of the hooked Agon spit: The Robin and Levoy (2007) model}

Using a set of 18 aerial photographs taken between 1947 and 2002, Robin and Levoy (2007) documented the stages and the rate of formation of the Agon spit (Fig. 4), proposing a model in which the influence on the shoreline of the swash bar located on the ebb delta is embodied in two consecutive morphological cycles. The bar and its onshore migration perturb the longshore transport, resulting in deposition (Robin et al., 2009a, b). Updrift of the bar, this disturbance leads to shoreline accretion. On the downdrift side, erosion results from the deficit in sediment supply, with the bar, and the tombolo that formed prior to bar attachment to the beach, further acting as natural breakwaters. The northward migration of the inlet channel leads to the formation of a sand platform that in turn induces a change in the orientation of the shoreline from SE to SSE, initiating the formation of a new hook. The welding of the bar and the resumption of the $\mathrm{N}-\mathrm{S}$ longshore transport regulate the shoreline and spit orientation towards the SE. This mechanism causes an inter-hook zone of $40-100 \mathrm{~m}$ which is then colonized by salt marshes. The lengthening and shape of the Agon spit seem to be controlled by the migration of swash bars on the ebb delta of Regnéville inlet. These bars influence the sediment flux and shoreline mobility over a timescale of several years. This model is original compared with others where the bar forms the main body of a new hook. Bar migration on the ebb delta takes approximately 12 years but the complete formation of a hook, considering the time of bar migration, took about 26 years during the period covered by the aerial photographs.

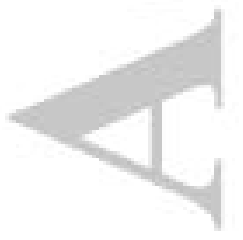




\section{Materials and methods}

\subsection{Morphological surveys}

\subsubsection{LiDAR and UAV}

To document and understand 3D morphological changes over large surfaces (> few square kilometres) such as those of a sand spit and its sedimentary environment, aerial measurements based on LiDAR technology or UAV photogrammetry are particularly suitable. They enable a short time acquisition of only a few hours at low tide but detailed imaging and mapping of morphological features. Airborne LiDAR has been in regular use in the study of high-resolution topographic changes along the coast of Normandy since February 2009 (Levoy et al., 2013; Montreuil et al., 2014; Levoy et al., 2017; Pellerin Le Bas and Levoy, 2018). The generated datasets have been acquired within the framework of the CLAREC project (French acronym for Contrôle par Laser Aéroporté des Risques Environementaux Côtiers), and are no doubt one of the densest LiDAR datasets in the world. The set of LiDAR data used for the present study were collected between 2009 and 2018 (Table 1), derived from 15 flights over the Regnéville basin and mouth of the inlet with up to two coverages a year using a Leica ASL60 (see Levoy et al., 2013, for technical details). The CLAREC project and the COZULIT project (acronym for Coastal Zone Changes and Risks Using Lidar Technology), its successor, provide digital elevation models (DEMs) with a $1 \mathrm{~m}$-grid size. The $\mathrm{X}$ and $\mathrm{Y}$ coordinates are relative to the Lambert 93 French National Grid, and the height, Z, refers to the IGN reference level (French Ordnance Datum), which is close to mean sea level. In this paper, we use the 
procedure described by Montreuil et al. (2014) on DEM of difference generation and associated errors.

As a complement to LiDAR data, UAV photogrammetry has also been conducted since 2017. The UAV data were collected in December 2017, June 2018 and April 2019 during experiments conducted in the framework of the UBECUS project (acronym of Uav BEach and Coastline sUrveyS). An Ebee Plus flying wing developed by Sensefly Company was used to obtain pictures used to elaborate Digital Surface Models (DSMs). The Ebee Plus integrates a 20 Mega-pixels SODA camera (Sensor Optimized for Drone Applications) and a IMU-GPS device. Typically, during the UBECUS project, flight heights varied between 90 and $140 \mathrm{~m}$, the associated pixel resolution was between 2 and $3 \mathrm{~cm}$, lateral overlap $70 \%$ and longitudinal overlap 80 or $85 \%$. For each campaign, a Dual frequency LEICA GPS 1200 base station was deployed on a known position to obtain a RINEX file used in PPK post-processing. Ground Control Points (GCPs) were deployed in the field (black and white marked targets) to improve the quality of the absolute $X, Y$ and $Z$ values of the final point cloud. In addition, other fixed horizontal surfaces (road, car park, ...) close to the study area were levelled using a mobile DGPS device and used as independent control surfaces to enhance the quality of $\mathrm{X}, \mathrm{Y}, \mathrm{Z}$ coordinates obtained by photogrammetry.

The coastal topography was obtained using PIX4D photogrammetry software (version 4.3.33) for drone mapping and 3D models. The PIX4D workflow is similar to that of Photoscan Agisoft software (Long et al., 2016; Chen et al., 2018): the first step is image alignment using common points (key points) identified on several images, the position of the camera for each image and taking into account the GCPs for accurate 
geolocation of the model; the second step is to create a dense point cloud in order to generate a mesh and a 3D textured mesh using the images; the last step is the calculation of the DSM and an orthomosaic with a spatial resolution of $5 \mathrm{~cm}$ for the study area. The comparison between the $\mathrm{X}, \mathrm{Y}, \mathrm{Z}$ coordinates measured with a dual frequency GPS at the centre of each GCP and X, Y, Z values obtained from photogrammetric processing allows for evaluation of the absolute accuracy of the mapped coastal topography. For instance, during the June 2018 flight, 29 GCPs were used. The mean difference between Xgps and Xuav is $-0.013 \mathrm{~m}$ with a rmse of 0.028 $\mathrm{m}, 0.015 \mathrm{~m}$ between Ygps and Yuav with a rmse of $0.029 \mathrm{~m}$, and $0.023 \mathrm{~m}$ between Zgps and Zuav with a rmse of $0.02 \mathrm{~m}$. The absolute topographic data obtained by UAV photogrammetry appears clearly better than those typically obtained from airborne LiDAR surveys (rmse close to $0.1 \mathrm{~m}$, Levoy et al., 2016).

\subsection{Hydrodynamics}

Between June $27^{\text {th }}, 2013$ and December $4^{\text {th }}, 2017$, a self-recording InterOcean S4DW electromagnetic current meter fitted with a pressure sensor, moored about 0.6 $\mathrm{m}$ above the sea bed, measured current velocities and directions, water-level variations, and directional wave characteristics. Fixed on a stainless-steel frame in the lower intertidal zone on the NW margin of the Agon ebb delta (Fig. 2), the instrument was programmed to record 9-min bursts of pressure and horizontal current fluctuations at a $2 \mathrm{~Hz}$ sampling frequency every $30 \mathrm{~min}$. This 9-min burst sampling was chosen as a compromise between two opposite constraints. It had to be large enough to allow spectral analysis but short enough to ensure a relatively stationary mean sea level. The wave characteristics were obtained from the measured time series by spectral 
analysis using Fast Fourier Transforms. The Fourier coefficients of the free surface elevation fluctuations were obtained from the corresponding ones computed from the pressure time series using the frequency-dependent transfer function inferred from linear theory. To avoid electronic noise, a frequency cutoff, kept constant during the tidal cycle and fixed at $0.27 \mathrm{~Hz}$, was applied after careful analysis of the data. Energy above $0.27 \mathrm{~Hz}$ was considered as spurious, caused by amplification of electronic noises (Levoy et al., 2000).

\section{Results}

\subsection{Topographic changes}

The Agon spit and its ebb delta evolved significantly during the survey period (February 2009 to April 2019) (Fig. 5). Three morphodynamic "stages" can be identified, involving the partial destruction of hook \#8 and the construction of a new one, hook \#9. Over this decade, the area near the spit hooks gained $244,100 \mathrm{~m}^{3}$ of sediment (24,000 $\mathrm{m}^{3} /$ year) (Fig.5d). These stages provide an overview of the evolution of the study site, following which a more detailed analysis of the pattern displayed by each stage is conducted.

\subsubsection{Definition of stages of morphological change}

Stage 1 (February 2009 to October 2013) was characterized by the erosion of the mid- and the high-tide zones along the spit (Fig. 5a). This erosion had, in fact, been on-going since 2004 (Robin 2007). The distal end of the hook gained sediment, allowing its elongation towards the SE, and abutting the channel which could no longer 
migrate freely due to the presence of a low-crested groyne located downdrift of the inlet (Fig. 2). During this period, the zone close to the hook (zone A in Fig. 2) gained $53,500 \mathrm{~m}^{3}$ of sediment $\left(11,400 \mathrm{~m}^{3} / \mathrm{year}\right)$ mainly in the mid-tide zone and the end of the hook platform. The swash bar on the ebb delta moved onshore and became parallel to the shoreline. Stage 2 (October 2013 to March 2016) was mainly characterized by pursuit of erosion of the mid- and high-tide zones that led to a lowering of the elevation of the hook. This erosion favoured marine submersion and breaching (Fig. 5b), and initially involved significant cross-shore translation and then complete destruction of the distal part of the hook. The swash bar on the ebb delta underwent alongshore elongation, evolving into a 'shore-parallel' bar. The zone close to the hook (zone A in Fig. 2) gained $113,400 \mathrm{~m}^{3}$ of sediments (46,900 $\mathrm{m}^{3} / \mathrm{year}$ ). Stage

3 (March 2016 to April 2019) was marked by the construction of a new clearlyindividualized hook (\#9) with the same shoreline orientation (NW-SE) (Fig. 5c). This hook originated from the longshore development of the 'shore-parallel' bar which constitutes its main body. During this stage, the zone close to the hook (zone A in Fig.

2) gained a total of $77,300 \mathrm{~m}^{3}$ of sediment ( $\left.25,000 \mathrm{~m}^{3} / \mathrm{year}\right)$.

\subsubsection{In-depth analysis of changes}

\section{a) Stage 1: Hook \#8 erosion (February 2009 to October 2013)}

During this stage, the distal part of the swash bar moved landward in an ESE direction for about $170 \mathrm{~m}$ under the influence of waves (Fig. 6). Its oblique orientation became less pronounced in the course of its migration, and it progressively became parallel to the shoreline starting from April 2011, resulting in the inception of a 'shore-parallel' bar. This migration proceeded apace with extension towards the SE, a process 
generated by longshore drift that was no longer interrupted by this bar. The area updrift of the bar was marked by supratidal accretion, resulting in overall shoreline advance, but involving erosion of the high-tide zone and an alternation of accretion/erosion on the higher part of the mid-tide zone. These changes exhibited a seasonal trend, stronger in winter and weaker in summer. The zone in the lee of the bar (bar shadow zone) underwent milder changes involving essentially erosion of the high-tide zone and the supratidal zone (February 2009-April 2010, September 2011-May 2012). The tidal flat in front of the bar did not undergo any significant change between surveys. Downdrift of the bar, along the hook, erosion of the mid- and high-tide zones attained significant values of $70 \mathrm{~m}$ on profile $\mathrm{C} 1$ and $80 \mathrm{~m}$ on profile $\mathrm{C} 2$ profile, and up to $18 \mathrm{~m}$ between two winter surveys (Fig. 7). This erosion was compensated by accretion of the supratidal section, at the dune foot. The combination of these two contrasting patterns resulted in a uniform beach profile between the top of the dune (9 m IGN69) and the mid-tide zone (2 m IGN69). Sand eroded along the hook was transported alongshore to feed the hook platform (Fig. 6), which extended $120 \mathrm{~m}$ to the SE, impinging, as mentioned above, on the channel inlet fixed downdrift by the low-crested groyne. The extension of this platform was marked by a gain in elevation $(+1.3 \mathrm{~m})$, attaining up to $7 \mathrm{~m}$ IGN69 (Fig.8). The platform also became wider with a 15-m expansion of the high-tide zone until September 2009 (C3), followed by a significant retreat of 90 m until October 2013, as observed in C1 and C2 (Fig. 7). The landward part of the spit was stable with only minor change over the four years. The width of the vegetated part of the spit narrowed by $45 \%$, down to only about $60 \mathrm{~m}$ in October 2013 . 


\section{b) Stage 2: Hook \#8 breaching and partial destruction (October 2013 to}

\section{March 2016)}

During this stage, the 'shore-parallel' bar moved slowly towards the SE (Fig. 9), its dynamics still controlled by longshore transport, resulting in its extension. Its tip switched progressively towards the $E$ and was in contact with the shoreline in June 2015 (Fig. 10). This development led to: (1) the emergence of a distinct tidal flat connected to the ebb delta by a narrow channel that persisted, probably due to strong tidal currents, as evidenced by the presence of $2 D-3 D$ dunes oriented in the ebb direction; (2) sustained erosion from stage 1 and weakening of the spit, culminating in its breaching and partial destruction of the hook (Fig. 10). This destruction took place during the course of three winters (Figs. 9, 12). The 2013-2014 winter led to the first breach event in the centre of the hook, an area not so well protected by the 'shoreparallel' bar. Erosion of the high-tide beach reached $34 \mathrm{~m}$ (profile C1; Fig.7) with sediment transfer towards the inner part of the flood delta in the form of a washover fan. This washover affected the spit over a distance of $220 \mathrm{~m}$ and resulted in a significant decrease in spit elevation from $9 \mathrm{~m}$ IGN69 to $7.3 \mathrm{~m}$ IGN69 on C1 for example (Fig. 7). The erosion of the high-tide zone impacted the entire spit down to the downdrift part of the bar (except its shadow zone, in accretion as the updrift side) and fed the end of the platform which remained blocked by the arrested position of the main channel. During the summer of 2014 and the second winter (2014-2015), the breach widened. The spit had become so narrow $(>30 \mathrm{~m})$ that it was completely destroyed during the third winter (2015-2016), following beach erosion and landward transfer of sand onto the inner part of the delta by overwash. Sentinel and Landsat satellite images show that it had resuscitated by December 29-30, 2015. Its 
destruction was thus a consequence of the three major but brief storms of $12 / 01,08 / 02$ and 09/03, 2016.

\section{c) Stage 3: formation of hook \#9 (March 2016 to April 2019)}

Following the destruction of hook \#8 and its platform during the previous stage, the inlet underwent complex morphological changes (Fig. 11). The various shoals resulting from the breakup of hook \#8, isolated from each other by the breach, were gradually eroded (C2 and C3) (Fig. 7). The sediment was mainly redistributed landward towards the flood delta by the strong tidal currents and by waves, or reworked and redistributed by the main channel. This led, in October 2016 and in December 2017, to the formation of a large mouth devoid of bedforms that was submerged whatever the tidal stage. Nevertheless, the main channel did not evolve freely since it remained attached to the groyne on the downdrift side of the inlet. This behaviour may be due to two causes: the zone remained maintained a high elevation (between 2 and $4 \mathrm{~m}$ IGN69), and the presence of a long and high transverse bar that took many years to form along the northern flank of the main channel disturbed its northward migration (Fig. 11A). The 'shore-parallel' bar continued its progression towards the SE but began to split in two. Its tip became detached from the main bar body and moved eastward (October 2016-December 2017; Fig. 11B) perturbing drainage of the tidal flat which was limited to only two small active channels. In fact, this 'inter-hook' zone was undergoing sediment gain and had begun to be colonized by seasonal vegetation. The remnants of the 'shore-parallel' bar had evolved in September 2018 into an isolated shoal between the spit (old and new) and the main channel. The main body of the bar continued to migrate towards the SE under the 
influence of longshore drift. Part of the bar had by then been well colonized by vegetation, clearly reinforcing its status as the new hook \#9 of the Agon spit.

\subsection{Hydrodynamic conditions}

Hydrodynamic conditions were recorded during stage 2 and part of stage 3 . The objective was to have an overview of the most morphogenic conditions that prevailed during these two periods. The approach here is to especially analyze wave conditions during high tides when breaching was observed. It should be noted that the last years of the study coincided with a particularly morphogenic phase of evolution of the west coast of Europe, affected by major storms (Castelle et al., 2018).

\subsubsection{Overview}

Significant wave heights (Hs), and wave periods and directions are depicted in Fig. 13. The vertical lines indicate when the LiDAR surveys were conducted. The average wave height over the 4.5-year survey period (from June 2013 to December 2017) was $0.38 \mathrm{~m}$. However, several severe winter storms were recorded with Hs values $>2.25$ m (return period of 10 years) (February and March 2016, January and October 2017) but with short durations, $<24 \mathrm{~h}$. Wave directions during these storms were quite identical $\left(270^{\circ}-287^{\circ}\right)$ and these events also corresponded to spring tides, > 6 m IGN69 at high tide during the peak of the storms. The lowest wave heights occurred during the summers. This seasonal contrast, not unexpected, was also observable by looking at the cumulative wave energy between surveys. 
In the absence of data during stage 1 (from February 2009 to October 2013), it is not possible to characterize the hydrodynamic environment that prevailed during winter conditions. During stage 2 (from October 2013 to March 2016), the 2015-2016 winter was the most energetic of all in the 4.5 years of surveys. A succession of three storms with peak Hs of up to $2.25 \mathrm{~m}$ occurred during spring tides. The two other winters were characterized by the passage of one (2014-2015) or two storms (2013-2014) with a 5-year return period but rarely linked to large tides (excepting February 2014). The two winters of stage 3 (from March 2016 to April 2019) were affected by one major storm (January and October 2017) with water levels > 6 m IGN69.

\subsubsection{Duration of operation of hydrodynamic processes}

The tidal environment induced highly variable immersion times depending on the elevation of the beach and the tidal range (Fig. 14). For example, a mean spring tide enabled flooding of the $5 \mathrm{~m}$ IGN69 level for $3 \mathrm{~h}$ per tidal cycle and of the $6.5 \mathrm{~m}$ IGN69 (MHWS limit) only for 45 minutes. Along the Agon spit, the $7 \mathrm{~m}$ IGN69 (and higher levels) were affected by hydrodynamic processes only for a short duration ( 1 h30) corresponding to an exceptional high spring tide. During phases of breaching, the 7.3 m IGN69 level (mean elevation of washover fan surfaces between May 2014 and June 2015 (Fig. 9b)) was flooded for 10 h (18/10/2013 to 15/05/2014), 8 h (15/05/2014 to 10/10/2014) and $9 \mathrm{~h}(10 / 10 / 2014$ to 03/06/2015). The durations were shorter when combined with Hs $>1 \mathrm{~m}: 7 \mathrm{~h}, 3 \mathrm{~h}$ and $1 \mathrm{~h}$ respectively. During the phase of partial destruction of the hook (30/12/2015 to 10/03/2016), the 7.3 m IGN69 level was flooded

for $5 \mathrm{~h}$, but only for $1 \mathrm{~h}$ with $\mathrm{Hs}>1 \mathrm{~m}$. During the February 2016 storm, this flooding phase lasted only 5 minutes with significant wave heights of $1.9 \mathrm{~m}$. During the March 
2016 storm, it lasted only 50 minutes with significant wave heights of $1.7 \mathrm{~m}$. These values must be considered as orders of magnitude given the various parameters that can locally modulate water level conditions. Once the end of spit hook \#8 was

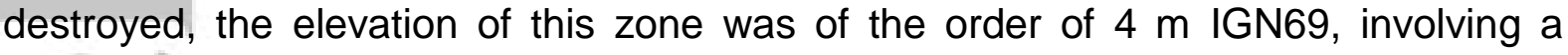
flooding phase of several hours per tidal cycle whatever the tidal range.

\section{Discussion}

The discussion will revolve around three points that also contribute to a better understanding of the dynamics of hooked spits in general: new insight on hooked spit dynamics and evolution relative to the previous model of Robin and Levoy (2007), the importance of overwash in mobilizing sediment in hooked spit systems, and the role of hydrodynamic conditions, notably the relationship between storms and the large tides, in modulating hooked spit evolution.

\subsection{New insight relative to the model of Robin and Levoy (2007)}

The evolution of the Agon Spit between 2009 and 2019 was marked by the creation of a new hook (\#9) at its distal extremity (Fig. 5). These observations are a follow-up on those of Robin and Levoy (2007) who documented the evolution of the spit from aerial photographs taken between 1972 and 2005 (Fig. 4), and highlighted the significant role of swash bar migration, notably culminating in the creation of hook \#8 in 1990. The role played by channel migration was also underpinned in that study, with regards to both the formation of a large platform and the creation of sufficient accommodation space for the new hook to develop towards the S. Up to October 2013 (Figs. 5, 6), the evolution of hook \#8 corresponded perfectly to the model of Robin and 
Levoy (2007). A swash bar progressively approached the high-tide beach. It's slow mobility, linked to the overarching influence of the large tidal range (Robin et al., 2007; Robin et al., 2009a), as discussed subsequently, perturbed longshore sediment transport and induced shoreline erosion downdrift that affected only the spit's beach profile and its dune front without generating overwash (Figs. 7, 8). The duration of this erosion ( $\approx 9$ years), on-going since 2004 as stated earlier, is about the same duration as that of the previous cycle ( $\approx 8$ years) (Robin, 2007). The end of the hook continued to progress slightly towards the SE. But starting from this point in time the evolution of the Agon spit diverges from the Robin and Levoy (2007) model (Fig. 15). The extremity of the spit shows a reduced width linked to sustained erosion over the last years, and has undergone severe phases of retreat by submersion that have led to spit breaching and backshore sediment transfers via washover fans, notwithstanding an elevation that is still relatively high, > 7.3 m NGF (Fig. 7). The strong winter storms of 2013-2014 and 2015-2016 are responsible for these changes. The influence of the recurved extremity of the swash bar, which had become a 'shore-parallel' bar in 2014, cannot be neglected, and the bar aggravated the weakening of the extremity of the spit and the breach zone (Figs. 9, 10, 12). Its elongation towards the ESE, almost in contact with the spit, created a runnel exiting close to the most fragile seaward part of the spit (June 2015). The runnel maintained communication with the ocean via a small but persistent opening subject to strong ebb currents, as shown by the formation of $2 \mathrm{D}$ and 3D dunes, that contributed to erosion of the breach (Fig. 10). The southern exposed part of the hook downdrift of the bar was also more vulnerable to wave action during spring tides. The total destruction of the extremity of hook \#8 occurred during the exceptional winter of $2015-2016$ with its succession of three storms with a 10 -year return interval and coinciding with large tides (Fig. 13). The erosion of the breach 
resulted in a lowering of its elevation, thus facilitating a large spring-tide freeboard during both flood and ebb. In the meantime, the 'shore-parallel' bar continued its elongation towards the SE under the influence of longshore drift. The bar assumed the same alignment as the previous hooks and became the nucleus of the new hook \#9, formed 27 years after \#8. This role of the bar as a new hook nucleus embodies a divergence from the previous model where the bar was simply a forcing element in the formation of hook \#8, and where this welding did not lead to breaching. The channel associated with hook \#8 migrated little over these years. Its $\mathrm{N}$ flank was bordered by a long and high transverse bar and its S flank by the low dike which tended to induce deepening at its extremity that further favoured its immobility (Fig. 2).

Taken individually, the various stages of formation of hook \#9 highlight a number of points that have been observed elsewhere: (i) for instance, the overall functioning of the spit resembles that proposed by Costas et al. (2006) from their field site in Spain (see their Fig. 15). The spit aggrades prior to erosion of its seaward flank and then becomes affected by overwash or overtoping; (ii) the downdrift erosion of the bar has been observed by other authors (Robin and Levoy, 2007; Costas and FitzGerald, 2011); (iii) the welding of swash bars that leads to the formation of a new hook corresponds to the main mechanism of hook development at inlets on the east coast of the United States, for instance (Hine, 1975, 1979; Aubrey and Speer, 1984; FitzGerald, 1984, 1988; Kana et al., 1999; FitzGerald et al. 1984, 2000; Borrelli and Wells, 2003; Lindhorst et al., 2008); (iv) finally, breaching and destruction of the extremities of hooks are regularly observed in the evolution of spits with or without hooks (e.g., Sanchez-Arcilla and Jimenez, 1994; Chaumillon et al., 2014; Williams et al., 2015; Safak et al., 2016; Sadio et al., 2017; Zainescu et al., 2019; Fruergaard et 
al., 2020). In addition to these points, the three stages of decadal evolution of the Agon spit, involving hook destruction followed by construction, also show that spit hooks can evince geomorphic resilience in the sense of Kombiadou et al. (2019b), undergoing morphological re-organization in a new hook involving a net positive sediment balance of $244,000 \mathrm{~m}^{3}$.

The concomitance of all these mechanisms in generating hook formation in the same site is rare and underpins the singularity of the Agon spit system. On the other hand, the construction of hook \#9 diverges from that of hook \#8 documented by Robin and Levoy (2007). This underscores the complexity of the formation of this type of coastal sediment body, which can involve several different processes over time acting on the same site and notwithstanding relatively constant forcing mechanisms.

\subsection{The role of overwash in large sediment mobilization in hooked spits}

Spits are known for their commonly dynamic behavior, especially under storm conditions. They are narrow, low-elevation landforms highly sensitive to changes in hydrodynamic conditions. Depending on the circumstances, strong waves occurring during high water levels (tides and storm surge) can erode or even breach them by overtopping and/or overwashing. Sediment transport induced by overwash constitutes a major issue in geological coastal processes because it can move large amounts of sand from the beach/dune face onto washover fans and the backbarrier environments. Significant progress has been made in recent decades in understanding the role of these marine flooding processes on morphological barrier/spit evolution (Sallenger, 2000; Morton and Sallenger, 2003; Donnelly et al., 2006; Matias et al., 2008, 2013; Chaumillon et al., 2017). Nevertheless, studies allowing a field quantification of 
sediment volume change during an overwash and inundation event are limited (e.g., Cloutier and Héquette, 1998; Stone et al., 2004; Matias, 2006; Carruthers et al., 2013; Rogers et al., 2015; Baumann et al., 2017; Engelstad et al., 2018; Suanez et al., 2018), and even more so in the case of a total destruction of a hook.

The Agon spit underwent several overwash events, notably in the course of storms between October 2013 and March 2016, as evidenced by the erosion and deposition zones at its tip (Fig. 12). Based on Lidar, this study has succeeded in quantifying the volumes of sediment mobilized during these events (Tabl. 2). $5820 \mathrm{~m}^{3}$ of sand was transported landward during winter 2013/2014, $2700 \mathrm{~m}^{3}$ during summer 2014 , and $6780 \mathrm{~m}^{3}$ during winter $2014 / 2015$. Our study confirms that overwashing and breaching can transport landward up to several hundreds of cubic metres per metre of beach width, confirming the work of Engelstad et al (2018). The area where overwash took place was wide, about 223 m during winter 2013/2014 and 206 m during winter $2014 / 2015$. The process always occurs in the same area, an overwash 'hotspot' where the absence of the 'shore-parallel' bar favours its activation each time, with a slightly southward extension over time, probably in relation with bar dynamics. Its throat width is in the upper average given in the literature (e.g., Matias et al., 2008; Hudock et al., 2014; Wesselman et al., 2019). The throat is located in an area of lower dune elevation, confirming that this parameter acts as a major morphological trigger on overwash occurrence (Sallenger, 2000). Concerning the partial destruction of a hook, the literature shows surface evolution patterns drawn from aerial or satellite photographs (Chaumillon et al., 2014; Williams et al., 2015; Fruergaard et al., 2020), but quantification of sediment volumes involved has lagged behind. At the Agon spit, the total destruction of the tip of the spit that took place during winter 2015-2016 is estimated at about $109,300 \mathrm{~m}^{3}$ (Tabl. 2). Slightly under $50 \%$ of this sediment was 
transferred landward $\left(54,200 \mathrm{~m}^{3}\right)$ and the rest $\left(55,100 \mathrm{~m}^{3}\right)$ probably redistributed into the ebb and flood deltas via the main channel (Fig. 12). This volume is important, especially when compared to the annual longshore transport, estimated at 40,000 $\mathrm{m}^{3} / \mathrm{yr}$. Thus, besides the fact that overwash is at the origin of important morphological changes affecting the Agon spit, the process occasionally represents a very important sediment exchange pathway in the spit-inlet-basin system.

Another point highlighted by the study is the relatively short duration of the overwash events in spite of these large sediment movements (Fig. 12), a point further discussed in 5.3 below. Overwash sedimentation is episodic, occurring during discrete events of varying magnitude and frequency (Matias, 2006). This is especially true in large tidal-range environments where the high-tide zone and dune are impacted by hydrodynamic processes over a short duration (spring high tides). During the winter 2013-2014 (but also summer 2014 and winter 2014-2015), the dune top had an elevation > 7.3m IGN.69 with a relatively steep front slope. This morphological configuration implies that the water level had to be higher to generate landward transport, as observed with the washover deposits. Such water levels coupled with moderate to energetic wave conditions $(\mathrm{Hs}>1 \mathrm{~m})$ are extremely rare in the study area. This correspond to only 438, 160 and 57 minutes during, respectively, winter 20132014, summer 2014 and winter 2014-2015. The partial destruction of hook \#8 is revealed by a Sentinel image and a Landsat image dated December 29 and 30, 2015. Thus, this destruction followed the three important but brief storms of January 12 , February 8, and March 9, 2016 year (Figs. 12, 13). However, the durations of these storms, combined with water levels higher > $7.3 \mathrm{~m}$ IGN69, point out a relatively short interval for the production of such important morphological changes (270 minutes or 
55 minutes with $\mathrm{Hs}>1 \mathrm{~m}$ (only the February and March storms)). Thus, our study shows that, despite the potential for a macrotidal context to drastically reduce the duration of overwash processes, these can induce, when they do occur, significant sediment mobilization and major morphological changes, of the same order of magnitude as those observed in micro-mesotidal environments.

\subsection{Tidal modulation of waves, and storm influence}

The Agon spit evolves in a large tidal-range environment (up to $11.15 \mathrm{~m}$ during mean spring tides) wherein North Atlantic Ocean waves are filtered by the shelf bathymetry but moderate wind waves can act with efficiency at high tide, especially during storms. This field site is therefore unique with the influence of the tide, storms, and wind waves on the morphodynamics of the spit and its delta. But confrontation of the morphological change data with hydrodynamic data still clearly shows that waves and wave-induced currents are the main process-drivers of spit evolution, as in settings with lower tidal ranges, with the large tidal range in Agon playing, nevertheless a significant role in the timing and intensity of change. Several consequences of this relationship between waves, storms and tides can be identified.

Concerning wave influence:

(i) Waves generate swash bar migration (Robin et al., 2007). During low energy conditions, tidal currents cannot generate landward bar mobility despite high mean velocities. Bar migration is observed only during storm conditions under surf-zone processes and their associated currents with mean flows directed onshore and an absence of bed return flows (Robin et al., 2009a, b). 
(ii) Waves lead to destruction of the spit and its platform during storms, as observed in this study between January and March 2016, and as reported in the literature (e.g., Sanchez-Arcilla and Jimenez, 1994; Cloutier and Héquette, 1998, Williams et al., 2015, Safak et al., 2016; Zainescu et al., 2019). Waves are therefore the main agent driving topographic changes in the spit and its delta.

(iii) Finally, waves produce longshore transport that nourishes the shore-parallel oriented bar and its evolution into a new hook (hook \#9) with its platform. This sediment input can vary over time as a function of meteorological variations. Although its impact has not been quantified in our study, this influence is probably less marked at the Agon spit than at other sites (e.g., Allard et al., 2008; Poirier et al., 2017). Perturbation of longshore transport by the presence of swash bars over long periods of several years (Robin and Levoy, 2007) seems to be an important constraining factor on the evolution of the tip of the spit.

Regarding the tidal influence, the durations of immersion periods in settings with large tidal ranges can vary considerably, spatially and temporally, over the neapspring tidal cycle (e.g., Masselink and Short, 1993; Reichmüth and Anthony, 2007; Robin et al., 2009a). Thus, the tide must also to be taken into consideration from several points of view:

(i) Robin et al., (2009a) showed that the slow rate of swash bar migration in Regnéville inlet was related to the duration of immersion: only $2 \mathrm{~h} 30$ during neap tides and $4 \mathrm{~h} 30$ during spring tides. As a result, the action of surf-zone processes is extremely reduced, inducing a low mean sediment transport. This slow bar migration durably hinders over several years longshore sand drift and the dynamics of the shoreline. 
(ii) The immersion duration of the upper high-tide zone along the spit is extremely reduced ( $1 \mathrm{~h}$ per tidal cycle above $5 \mathrm{~m}$ IGN69 for mean tides and $3 \mathrm{~h}$ per tidal cycle for mean spring tides (Figs. 13, 14). Similarly, the spit platform, which is always submerged in micro-mesotidal environments (Meistrell, 1966; Hayes, 1980; Nielsen et al., 1988, Balouin et al., 2001), is affected by hydrodynamic processes (near $6.5 \mathrm{~m}$ IGN69 in the field site) only 45 minutes per tidal cycle for mean spring tides. The tidal context therefore plays an important role when one attempts to understand the original pattern and duration of the formation cycle of a new spit, which is very long compared to microtidal environments (FitzGerald, 1984; Smith and FitzGerald, 1994; Gaudiano and Kana, 2001). This is also the case concerning the destruction of the hook which occurs over a long period of several years. It is the succession of short periods (overwash $1,2,3$ ) representing a combination of an energetic event and a sufficiently high tide level (Fig. 12) that leads to breaching and hook tip destruction. These periodic events engender a step-by-step destabilization of the hook before its final destruction. (iii) Despite the fact that mean tidal currents can reach $1 \mathrm{~m} / \mathrm{s}$ in the $\mathrm{mid} / \mathrm{high}$-tide zones (Robin et al., 2009a), these flows have a low morphogenic capacity. During low energy conditions, only minor changes are observed along the spit and the delta (summer period). Only transverse bars are seen to migrate northwards under the low prevailing mean currents (Levoy et al., 2013, Montreuil et al., 2014). However, an exception in the course of breaching and destruction of the spit concerns strong mean currents associated with channel flow during high tides, which contribute to maintaining and reinforcing incision of the breach in the case where the threshold elevation has been reached, whatever the wave energy. The presence of $2 D-3 D$ dunes on the washover fans or near the inlet indicates the existence of these strong channel currents. They further contribute to the redistribution of sediment over the ebb and flood deltas. 
Our study, carried out in a megatidal context, thus highlights the duality of the two major forcing agents affecting the study site. Wave action is the main factor leading to topographic changes as observed in micro-mesotidal environments, whereas the tide plays an important role due to the water depth variations it induces. This latter condition leads to a longer duration of construction compared to the lower tidal-range environments, but the duration of destruction of the system remains short. Tidal currents or forced tidal flows further play a complementary role in macrotidal environments. These observations bear on the timescales of change. Inertia prevails over long periods of time punctuated by rapid change over short periods of time, both time frames mediated by tides.

\section{Conclusion}

Results obtained from the analysis of a dense temporal series of $3 D$ aerial topographic surveys (LiDAR and UAV) over a decade (on average, two coverages per year between 2009 and 2019) highlight the utility of these sources of high-resolution data in unravelling the complex morphodynamics of spit hook development in a tidal environment, especially when complemented by in-situ hydrodynamic measurements. Various processes have been evoked to explain the formation of new spit hooks but these have virtually exclusively focused on microtidal to mesotidal environments. At the macrotidal Agon spit, the role played by a swash bar on an adjacent ebb tidal delta is crucial. When located in the mid and high-tide zones, the bar disrupts the N-S sediment transport, facilitating progradation of the shoreline updrift of the bar. The bar also protects the shoreline from storm effects and overwash processes. On the other end, downdrift of the bar, a sediment deficit renders the shoreline fragile and subject to erosion. This fragility favours overwash and spit breaching. Three spates of 
landward sediment transfers of about $5820 \mathrm{~m}^{3}, 2700 \mathrm{~m}^{3}$ and $6780 \mathrm{~m}^{3}$ occurred approximately at the same 'overwash hotspot' location, and culminated in a $220 \mathrm{~m}$ wide breach. Overwash events tend to occur during short periods of time (few hours) when a high water-level (spring high tide) occurs in conjunction with relatively energetic wave activity, thus highlighting the important role of tides, but also storms. Breaching is followed by a long duration of hook formation as the large tidal range generates morphological inertia. This is unlike low to moderate tidal-range settings where waves and longshore sand transport gradients continuously determine the evolution of spit hooks. The cycle of hook formation, breaching and reconstruction of the Agon spit involved a gain of sediment of about $244,000 \mathrm{~m}^{3}$ in 10 years, thus illustrating the highly dynamic nature of these features, while underpinning their geomorphic resilience in this large tidal-range setting. Finally, the results call into question the repetitiveness of a single process in the creation of hooks of the same spit, highlighting divergence with an earlier and simpler model of spit hook development reported by Robin and Levoy (2007), similarly associated with swashbar influence but not involving breaching. Thus, for the same study site, the range of processes involved in spit hook evolution can be different for different hooks.

\section{Acknowledgements}

This study was supported in part by CNRS-INSU and four French regions: BasseNormandie, Haute-Normandie, Picardie and Nord-Pas-de-Calais during the Lidar CLAREC project (2008-2014). The Agon Spit is a monitoring site of the Service National d'Observation (SNO) Dynalit (https://www.dynalit.fr) which also provided, together with the Conseil Départemental de la Manche, financial support for the surveys. The authors would like to thank the CLAREC team for conducting the LiDAR 
surveys, especially Patrice Bretel who prepared the data. Thanks also to the CREC technical team for the deployment of S4 current meters and for the UAV flights, especially Jean-Paul Lehodey, Yoann Bonte and Guillaume Izabel. Stuart Lane and two anonymous reviewers provided salient suggestions for improvement of the manuscript.

\section{Data availability statement}

The data used in this study are available upon request to authors.

\section{Conflict of interest statement}

The authors declare that they do not have any conflict of interest.

\section{References}

Adams PN, Keough KM, Olabarrieta M. 2015. Beach morphodynamics influenced by an ebb-tidal delta on the North Florida Atlantic Coast. Earth Surface Processes and Landforms 41: 936-950.

Allard J, Bertin X, Chaumillon E, Pouget F. 2008. Sand spit rhythmic development: A potential record of wave climate variations? Arçay spit, western coast of France. Marine Geology 253: 107-131.

Ashton A, Murray AB, Arnoult O. 2001. Formation of coastline features by large-scale instabilities induced by high-angle waves. Nature 414: 296-300. 
Ashton AD, Nienhuis J, Ells. 2016. On a neck, on a spit: controls on the shape of free spits. Earth Surface Dynamic 4: 193-210.

Aubrey DG, Speer PE. 1984. Updrift migration of tidal inlets. Journal of Geology 92: $531-546$

Balouin Y, Howa H, Michel D. 2001. Swash platform morphology in the ebb-tidal delta of the Barra Nova inlet, South Portugal. Journal of Coastal Research 17(4): 784-791. Baumann, J., Chaumillon, E., Bertin, X., Schneider, J.L., Guillot, B., and Schmutz, M., 2017. Importance of infragravity waves for the generation of washover deposits. Marine Geology, 391, 20-35.

Billy J, Robin N, Hein C, FitzGerald D, Certain R. 2018a. Impact of relative sea-level changes since the last deglaciation on the formation of a composite paraglacial barrier. Marine Geology 400: 76-93.

Billy J, Robin N, Hein C, FitzGerald D, Certain R. 2018b. Primary influence of inherited geologic framework on the development of a coastal barrier system. Journal of Coastal Research SI 85: 406-410.

Borrelli M, Wells JT. 2003. Swash bars and spits growth: Evolution of a rapidely prograding spit along a sediment-starved coast. Proceedings of Coastal Sediments 2003, ASCE, Floride. 
Brock JC, Purkis SJ. 2009. The emerging role of lidar remote sensing in coastal research and resource management. Journal of Coastal Research SI 53: 1-5.

Carruthers EA, Lane DP, Evans RL, Donnelly JP, Ashton AD. 2013. Quantifying overwash flux in barrier systems: An exemple from Martha's Vineyard, Massachusetts, USA. Marine Geology 343: 15-28.

Carter RWG. 1988. Coastal Environments - An introduction to the Physical, Ecological and Cultural Systems of Coastlines. Academic Press London, 617p.

Castelle B, Dodet G, Masselink G, Scott T. 2018. Increased winter-mean wave height, variability and periodicity in the North-East Atlantic over 1949-2017. Geophysical Research Letters 45(8): 3586-3596.

Chaumillon E, Ozenne F, Bertin X, Long N, Ganthy F. 2014. Control of wave climate and meander dynamics on spit breachingand inlet migration. Journal of Coastal Research SI. 70: 109-114.

Chaumillon E, Bertin X, Fortunato AB, Bajo M, Schneider JL, Dezileau L, Walsh JP, Michelot A, Chauveau E, Créach A, Hénaff A, Sauzeau T, Waeles B, Gervais B, Jan G, Baumann J, Breilh JF, Pedreros R. 2017. Storm-induced marine flooding: lessons from a multidisciplinary approach. Earth-Science Reviews 165: 151-184. 
Chen, B., Yang, Y., Wen, H., Ruan, H., Zhou, Z., Luo, K., Zhong, F., 2018. Highresolution monitoring of beach topography and its change using unmanned aerial vehicle imagery. Ocean \& Coastal Management 160: 103-116.

Cloutier M, Héquette A. 1998. Aeolian and overwash sediment transport across a low barrier spit, southeastern Canadian Beaufort Sea. Zeitschrift für Geomorphologie 42 (3), 349-365.

Cooper JAG, Green AN, Loureiro C. 2018. Geological constraints on mesoscale coastal barrier behavior. Global and Planetary Change 168: 14-34

Costas S, Alejo I, Rial F, Lorenzo H, Nombela MA. 2006. Cyclical evolution of a modern transgressive sand barrier in northwestern spain elucidated by gpr and aerial photos. Journal of sedimentary research 76 (9): 1077-1092.

Costas S, FitzGerald D. 2011. Sedimentary architecture of a spit-end (Salisbury beach, Massachusetts): The imprints of sea-level rise and inlet dynamics. Marine Geology 284: 203-2016.

Donnelly C, Kraus N, Larson M. 2006. State of knowledge on measurement and modeling of coastal overwash. Journal of Coastal Research 22-4: 965-991.

Elias EPL, Stive MJF, Roelvink JA. 2002. Morphodynamics at the updrift side of the inlets. Proceedings $28^{\text {th }}$ International Conference on Coastal Engineering 2002, Cardiff, 197-209. 
Engelstad A, Ruessink BG, Hoekstra P, Van der Vegt M. 2018. Sand suspension and transport during inundation of a Dutch Barrier Island. Journal of Geophysical Research: Earth Surface 123 (12): 3292-3307.

Escudero M, Silva R, Hesp PA, Mendoza E. 2019. Morphological evolution of the sandspit at Tortugueros beach, Mexico. Marine Geology 407: 16-31.

Evans OF. 1942. The Origin of Spits, Bars, and Related Structures. Journal Geology 50: 846-865. -In: Schwartz, M.L. (eds.) (1972). Spits and Bars. Dowden, Hutchinson \& Ross, Stroudsberg, PA, 452p.

Fenster M, Dolan R. 1996. Assessing the impact of tidal inlets on adjacent barrier island shorelines. Journal of Coastal Research 12(1): 294-310.

Firth CR, Smith DE, Hansom JD, Pearson SG. 1995. Holocene spit development on a regressive shoreline, Dornoch Firth, Scotland. Marine Geology 124: 203-214.

FitzGerald DM. 1984. Interactions between the ebb-tidal delta and landward shoreline: Price Inlet, South Carolina. Journal of Sedimentary Petrology 54(4): 1303-1318.

FitzGerald DM. 1988. Shoreline erosional-depositional processes associated with tidal inlets. In: D.G. Aubrey \& L. Weishar (eds.): Lecture notes on coastal and estuarine studies: Hydrodynamics and sediment dynamics of tidal inlets. New York, SpingerVerlag, 29, 186-224. 
FitzGerald DM, Penland S, Nummedal D. 1984. Control of barrier island shape by inlet sediment bypassing: East Frisian Islands, West Germany. Marine Geology 60: 355376.

FitzGerald DM, Buynevich IV, Fenster MS, McKinlay PA. 2000. Sand dynamics at the mouth of a rock-bound, tide-dominated estuary. Sedimentary Geology 131: 25-49.

Fox WT, Haney RL, Curran HA. 1995. Penouille spit, evolution of a complex spit, Gaspé, Quebec, Canada. Journal of Coastal Research 11(2): 478-493.

Fruergaard M, Tessier B, Poirier C, Mouazé, Weill P, Noël S. 2020. Depositional controls on a hypertidal-spit system architecture and evolution, Pointe du Banc spit, north-western France. Sedimentology 67: 502-533.

Galichon P. 1984. Hydrodynamique sédimentaire des flèches littorales sableuses: cas de la Pointe d'Arcay (Vendée). Thèse Université de Paris-Sud, Centre d'Orsay, $216 p$.

Garel E, Sousa C, Ferreira O, Morales JA. 2014. Decadal morphological response of an ebb-tidal delta and down-drift beach to artificial breaching and inlet stabilization. Geomorphology 216: 13-25. 
Gaudiano DJ, Kana TW. 2001. Shoal bypassing in mixed energy inlets: geomorphic variables and empirical predictions for nine South Carolina Inlets. Journal of Coastal Research 17(2): 280-291.

Gilbert GK. 1890. Lake Bonnerville. U.S. Geol Survey Monograph, 1, 23-65. - In:

Schwartz, M.L. (eds.) 1972. Spits and Bars. Dowden, Hutchinson \& Ross, Stroudsberg, $P A, 452 p$.

Guilcher A. 1954. Morphologie littorale et sous marine. Presse universitaire de France, $215 p$.

Gutierrez R, Gibeaut JC, Smyth RC, Hepner TL, Andrews JR. 2001. Precise airborne LiDAR surveying for coastal research and geohazards applications. In Proceedings of the ISPRS Workshop "Land Surface Mapping and Characterization Using Laser Altimetry", Annapolis,MD, USA, October 22-24, 2001; In International Archives of Photogrammetry, Remote Sensing and Spatial Information Sciences, ISPRS: Vienna, Austria, 2001; Volume 34-3/W4, pp. 22-24.

Hayes MO. 1980. General morphology and sediment patterns in tidal inlets. Sedimentary Geology 26 : 139-156.

Hallégouët B. 1981. Les crêtes littorales dunifiées du massif Armoricain, France : formation et évolution. Géographie physique et Quaternaire XXXV(2) : 205-218. 
Hein CJ, Fallon AR, Rosen P, Hoagland P, Georgiou IY, FitzGerald DM, Morris M, Baker S, Marino GB, Fitzsimons G. 2019. Shoreline Dynamics Along a Developed River Mouth Barrier Island: Multi-Decadal Cycles of Erosion and Event-Driven Mitigation. Frontiers in Earth Science 7:103.

Héquette A, Ruz, MH. 1991. Spit and barrier island migration in the Southeastern Canadian Beaufort Sea. Journal of Coastal Research 7(3): 677-698.

Hicks DM, Hume TM, Swales A, Green MO. 1999. Magnitudes, spatial extent, time scales and causes of shoreline change adjacent to an ebb tidal delta, Katikati inlet, New Zealand. Journal of Coastal Research 15(1): 220-240.

Hine AC. 1975. Bedform distribution and migration pattern on tidal deltas in the Chatmam Harbor Estuary, Cape Cod, Massachusetts. - In: L.E. Cronin (eds.), Estuarine Research. Academic Press, New York, 2, 235-252.

Hine AC. 1979. Mechanisms of berm development and resulting beach growth along a barrier spit complex. Sedimentology 26: 333-351.

Hopkins J, Elgar S, Raubenheimer B. 2017. Flow separation effects on shoreline sediment transport. Coastal Engineering 125: 23-27.

Hudock JW, Flaig PP, Wood LL. 2014. Washover fans: A modern geomorphologic analysis and proposed classification scheme to improve reservoir models. Journal of Sedimentary Research 84: 854-865. 
Kana TW, Hayter EJ, Work PA. 1999. Mesoscale sediment transport at Southeastern U.S. tidal inlets: Conceptual model applicable to mixed energy settings. Journal of Coastal Research 15(2): 303-313.

King CAM. 1970. Changes in the Spit at Gibraltar Point, Lincolnshire, 1951 to 1969. East. Midl. Geol. 5: 19-30. In: Schwartz, M.L. (eds.) (1972). Spits and Bars. Dowden, Hutchinson \& Ross, Stroudsberg, PA, 452p.

King CAM, McCullagh J. 1971. A simulation model of a complex recurved spit. Journal of Geophysical Research 79: 22-37. In: Schwartz, M.L. (eds.) (1972). Spits and Bars. Dowden, Hutchinson \& Ross, Stroudsberg, PA, 452p.

Kombiadou K, Matias A, Ferreira O, Carrassco AR, Costas S, Plomaritis T. 2019a. Impacts of human interventions on the evolution of the Ria Formosa barrier island system (S. Portugal). Geomorphology: 343, 129-144.

Kombiadou, K., Costas, S., Carrasco, A.R., Plomaritis, T.A., Ferreira, O., Matias, A., 2019b. Bridging the gap between resilience and geomorphology of complex coastal systems. Earth-Science Reviews, 198: 102934. https://doi.org/10.1016/i.earscirev.2019.102934

Kosyan RD, Krylenko MV. 2019. Modern state and dynamics of the Sea of Azov coasts. Estuarine, Coastal and Shelf Science 224 : 314-323. 
Levoy F. 1994. Evolution et fonctionnement hydrosédimentaire des plages macrotidales - L'exemple de la côte ouest du Cotentin. Thèse Université de Caen, $424 p$.

Levoy F, Anthony EJ, Monfort O, Larsonneur C. 2000. The morphodynamics of megatidal beaches in Normandy, France. Marine Geology 171: 39-59.

Levoy F, Monfort O, Larsonneur C. 2001. Hydrodynamic variability on megatidal beaches, Normandy, France. Continental Shelf Research 21: 563-586.

Levoy F, Anthony EJ, Monfort O, Robin R, Bretel P. 2013. Formation and migration of transverse bars along a tidal sandy coast deduced from multi-temporal Lidar datasets. Marine Geology 342: 39-52.

Levoy F, Garestier F, Froideval L, Monfort O, Poullain E. 2016. Contributions of airborne topographic LiDAR to the study of coastal systems, Chapter 6. In: Baghdadi, N. and Zribi, M. (eds.), Land Surface Remote Sensing in Urban and Coastal Areas. Amsterdam: Elsevier, pp. 231-268.

Levoy F, Anthony E, Dronkers J, Monfort O, Izabel G, Larsonneur C. 2017. Influence of the 18.6-year lunar nodal tidal cycle on tidal flats: Mont-Saint-Michel Bay, France. Marine Geology 387: 108-113. 
Lindhorst S, Betzler C, Hass HC. 2008. The sedimentary architecture of a Holocene barrier spit (Sylt, German Bight): Swash-bar accretion and storm erosion. Sedimentary Geology 206: 1-16.

Long N, Millescamps B, Guillot B, Pouget F, Bertin X. 2016. Monitoring the topography of a dynamic tidal inlet using UAV imagery. Remote Sensing, MDPI, Special Issue, Remote Sensing in Coastal Environments 8: 387.

Masselink G, Short AD. 1993. The effect of tide range on beach morphodynamics and morphology: a conceptual beach model. Journal of Coastal Research 9(3): 785-800.

Matias A. 2006. Overwash sediment dynamics in the Ria Formosa Barrier Islands. Phd University of Algarve, 276p.

Matias A, Ferreira O, Vila-Concejo A, Garcia T, Alveirinho Dias J. 2008. Classification of washover dynamics in barrier islands. Geomorphology 97: 655-674.

Matias A, Masselink G, Kroon A, Blenkinsopp CE, Turner IL. 2013. Overwash experiment on a sandy barrier. Journal of Coastal Research 1(65): 778-783.

Meistrell FJ. 1966. The spit-platform concept: Laboratory observation of spit development. Thesis at university of Edmonton, Alberta. - in: Schwartz, M.L. (1972). Spits and Bars. Dowden, Hutchinson \& Ross, Stroudsberg, PA, 452p. 
Miselis JL, Lorenzo-Trueba J. 2017. Natural and human-induced variability in barrierisland response to sea level rise. Geophysical Research Letters 44/23: 11922-11931.

Montreuil AL, Levoy F, Bretel P, Anthony EJ. 2014. Morphological diversity and complex sediment recirculation on the ebb delta of a macrotidal inlet (Normandy, France): A multiple LiDAR dataset approach. Geomorphology 219: 114-125.

Morton RA, Sallenger AH. 2003; Morphological impacts of extreme storms on sandy beaches and barriers. Journal of Coastal Research 19 (3): 560-573.

Murray AB, Ashton A, Arnoult O. 2001. Large-scale morphodynamic consequences of an instability in alongshore transport. Proceedings of the International Association for hydraulic Research Symposium on River, Coastal and Estuarine Morphodynamics, Obihiro, Japan, September 10-14 2001.

Nahon A, Idier D, Sénéchal N, Féniès H, Mallet C, Mugica J. 2019. Imprints of wave climate and mean sea level variations in the dynamics of a coastal spit over the last 250 years: Cap Ferret, SW France. Earth Surface Procesess and Landforms 44-11: $2112-2125$.

Nielsen LH, Johanssen PN, Surlyk F. 1988. A late Pleistocene coarse-grained spitplatform sequence in northen Jylland, Denmark. Sedimentology 35: 105-119. 
Okyay, U., Telling, J., Glennie, C.L., Dietrich, W.E., 2019. Airborne lidar change detection: An overview of Earth sciences applications. Earth-Science Reviews 198: 102929. https://doi.org/10.1016/j.earscirev.2019.102929

Ollerhead J, Davidson-Arnott RGD. 1995. The evolution of Buctouche Spit, New Brunswick, Canada. Marine Geology 124: 215-236.

Pellerin Le Bas X, Levoy F. 2018. Bar migrations on a macrotidal ebb delta over a period of six years using LiDAR survey. In: Shim, J.S., Chun, I., Lim, H.S. (eds.), Proceedings from the International Coastal Symposium (ICS) 2018 (Busan, Republic of Korea). Journal of Coastal Research, Special Issue No. 85, pp. 1-5. Coconut Creek (Florida), ISSN 0749-0208.

Petersen D, Deigaard R, Fredsøe J. 2008. Modelling the morphology of sandy spits. Costal Engineering 55: 671-684.

Poirier C, Tessier B, Chaumillon E. 2017. Climate control on late Holocene highenergy sedimentation along coasts of the northeastern Atlantic Ocean. Paleogeography, Paleoclimatology, Paleoecology 485: 784-797.

Powell MA, Thieke RJ, Mehta AJ. 2006. Morphodynamic relataionships for ebb and flood delta volumes at Florida's entrances. Ocean Dynamics 56: 295-307. 
Psuty, N.P., Spahn, Sylveira, Schmelz, W., 2014. Sediment budget as a driver for sediment management at plumb beach, New York, USA: vectors of change and impacts. Journal of Coastal Conservation 18: 515-528.

Randazzo G, Jackson D, Cooper A. 2015. Sand and gravel spits. In: Coastal

Research Library. vol. 12. Springer, pp. 327-340.

Reichmüth B, Anthony EJ. 2007. Tidal influence on the intertidal bar morphology of two contrasting macrotidal beaches. Geomorphology 90 (1-2): 101-114.

Riggs SR, Cleary WJ, Snyder SW. 1995. Influence of inherited geologic framework on barrier shoreface morphology and dynamics. Marine Geology 126 : 213-234.

Robin N. 2007. Morphodynamique des systèmes de flèches sableuses: Etude entre les embouchures tidales de l'Archipel de St Pierre et Miquelon et de la côte ouest du Cotentin (Manche). University of Caen, Unpublished Ph.D thesis, 529 p.

Robin N, Levoy F. 2007. Etapes et rythmes de formation d'une flèche sédimentaire à crochets multiples en environnement megatidal. Zeitschrift für Geomorphologie 51: 337-360.

Robin N, Levoy F, Monfort O. 2007. Bar Morphodynamic Behaviour on the Ebb Delta of a Macrotidal Inlet (Normandy, France). Journal of Coastal Research 23(6): 13701378. 
Robin N, Levoy F, Monfort O. 2009a. Short term morphodynamics of an intertidal bar on megatidal ebb delta, Marine Geology 260: 102-120.

Robin N, Levoy F, Monfort O, Anthony EJ. 2009b. Short-term to multi-decadal scale onshore bar migration and shoreline changes in the vicinity of a megatidal ebb delta. Journal of Geophysical Research 114: F04024, doi: 10.1029/2008JF001207.

Rogers LJ, Moore L, Goldstein EB, Hein CJ, Lorenzo-Trueba J, Ashton A. 2015. Anthropogenic controls on overwash deposition: Evidence and consequences. Journal of Geophysical Research: Earth Surface 120 (12): 2609-2624.

Ruz MH. 1989. Recent evolution of the southeast barrier coast of Ireland. Journal of Coastal Research 5: 523-539.

Sadio M, Anthony EJ, Diaw AT, Dussouillez P, Fleury JT, Kane A, Almar R, Kestenare E. 2017. Shoreline changes on the wave-influenced Senegal River delta, West Africa: The roles of natural processes and human interventions. Water 9 (5): 357. doi:10.3390/w9050357

Safak I, Warner JC, List JH. 2016. 'Barrier island breach evolution: Alongshore transport and bay-ocean pressure gradient interactions. Journal of Geophysical Research: Oceans 121: 8720-8730.

Sallanger AHJr. 2000. Storm impact scale for barrier islands. Journal of Coastal Research 16: 890-895. 
Sanchez-Arcilla A, Jimenez JA. 1994. Breaching in a wavedominated barrier spit: the Trabucador Bar (Northeastern Spanish coast). Earth Surface Processes and Landforms 19: 483-498

Sanderson PG, Eliot I. 1996. Shoreline salients, cuspate forelands and tombolos on the coast of Western Australia. Journal of Coastal Research 12(3): 761-773.

Schwartz ML. 1972. Spits and Bars. Dowden, Hutchinson \& Ross, Stroudsberg, PA, $452 p$.

Smith JB, FitzGerald DM. 1994. Sediment transport at the Essex River inlet ebb-tidal delta, Massachusetts, U.S.A. Journal of Coastal Research 10(3): 752-774.

Stéphan P, Suanez S, Fichaut B, Autret R, Blaise E, Houron J, Ammann J, Grandjean P. 2018. Monitoring the medium-term retreat of a gravel spit barrier and management strategies, Sillon de Talbert (North Brittany, France). Ocean and Coastal Management 158: $64-82$.

Stone GW, Liu B, Pepper DA, Wang P. 2004. The importance of extratropical and tropical cyclones on the short-term evolution of barrier islands along the northern Gulf of Mexico, USA. Marine Geology 210 : 63-78.

Suanez S, Stéphan P, Floc'h F, Autret R, Fichaut B, Blaise E, Houron J, Ammann J, Grandjean P, Accensi M, André G, Ardhuin F. 2018. Fifteen years of hydrodynamics 
forcing and morphological changes leading to breaching of a gravel spit, Sillon de Talbert (Brittany). Géomorphologie: Relief, Processus, Environnement 24 (4) : 403428.

Van de Plassche O, Van Heteren S. 1997. Influence of relative sea-level change and tidal-inlet development on barrier-spit stratigraphy, Sandy Neck, Massachusetts. Journal of Sedimentary Research 67: 350-363.

Van Heteren S, Oost A, Van der Spek Ad.J.F, Elias EPL. 2006. Island-terminus evolution related to changing ebb-tidal-delta configuration: Texel, The Netherlands. Marine Geology 235: 19-33.

Van Rijn LC. 1998. Principles of coastal morphology. Aqua Publications, Amsterdam, The Netherlands, 730p.

Wesselmann D, De Winter R, Oost A, Hoekstra P, Van der Vegt M. 2019. The effect of washover geometry on sediment transport during inundation events. Geomorphology 327: 28-47.

Williams JJ, Esteves LS, Rochford LA. 2015. Modelling storm responses on a highenergy coastline with XBeach. Modeling Earth Systems Environment 1-2, Article:3.

Zainescu FJ, Vespremenu-Stroe A, Tatui F. 2019. The formation and closure of the Big Breach of Sacalin spit associated with extreme shoreline retreat and shoreface erosion. Earth Surface Processes and Landforms 44 (11): 2268-2284. 
Zenkovitch VP. 1959. On the genesis of cuspate spits along lagoon shores. Journal of Geology 67(3): 269- 277.

Zenkovitch VP. 1967. Processes of coastal development. Olivier and Boyd, Edinburgh, Scotland, $738 p$.

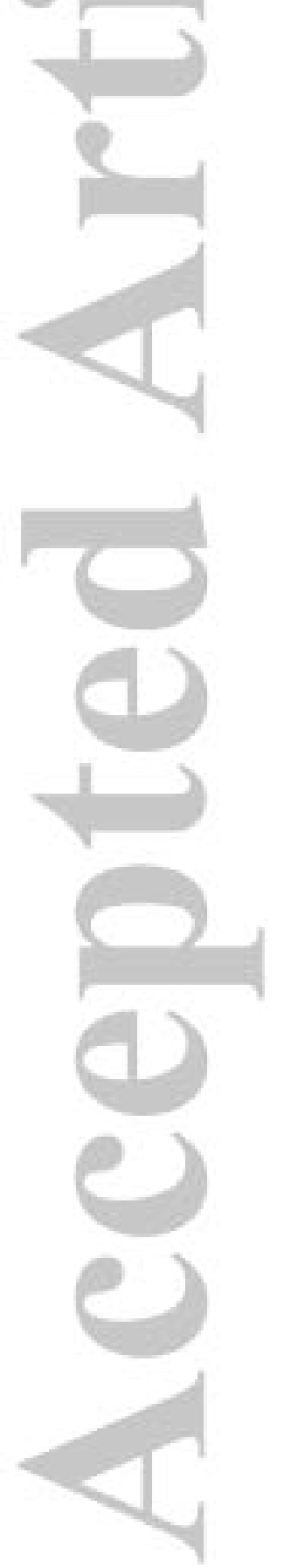




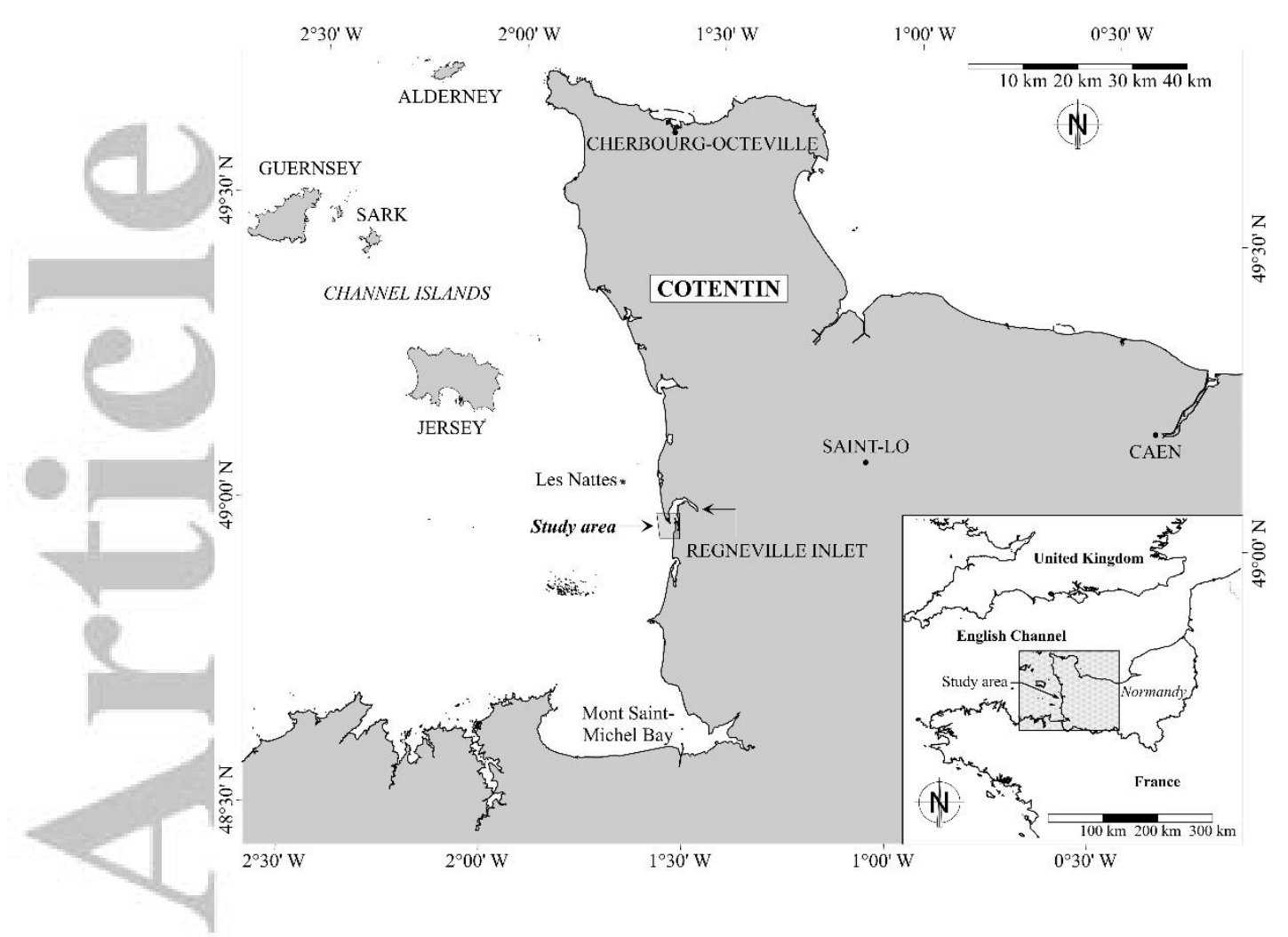

Fig. 1. Location of Agon Spit and Regnéville Inlet in Normandy, France. 


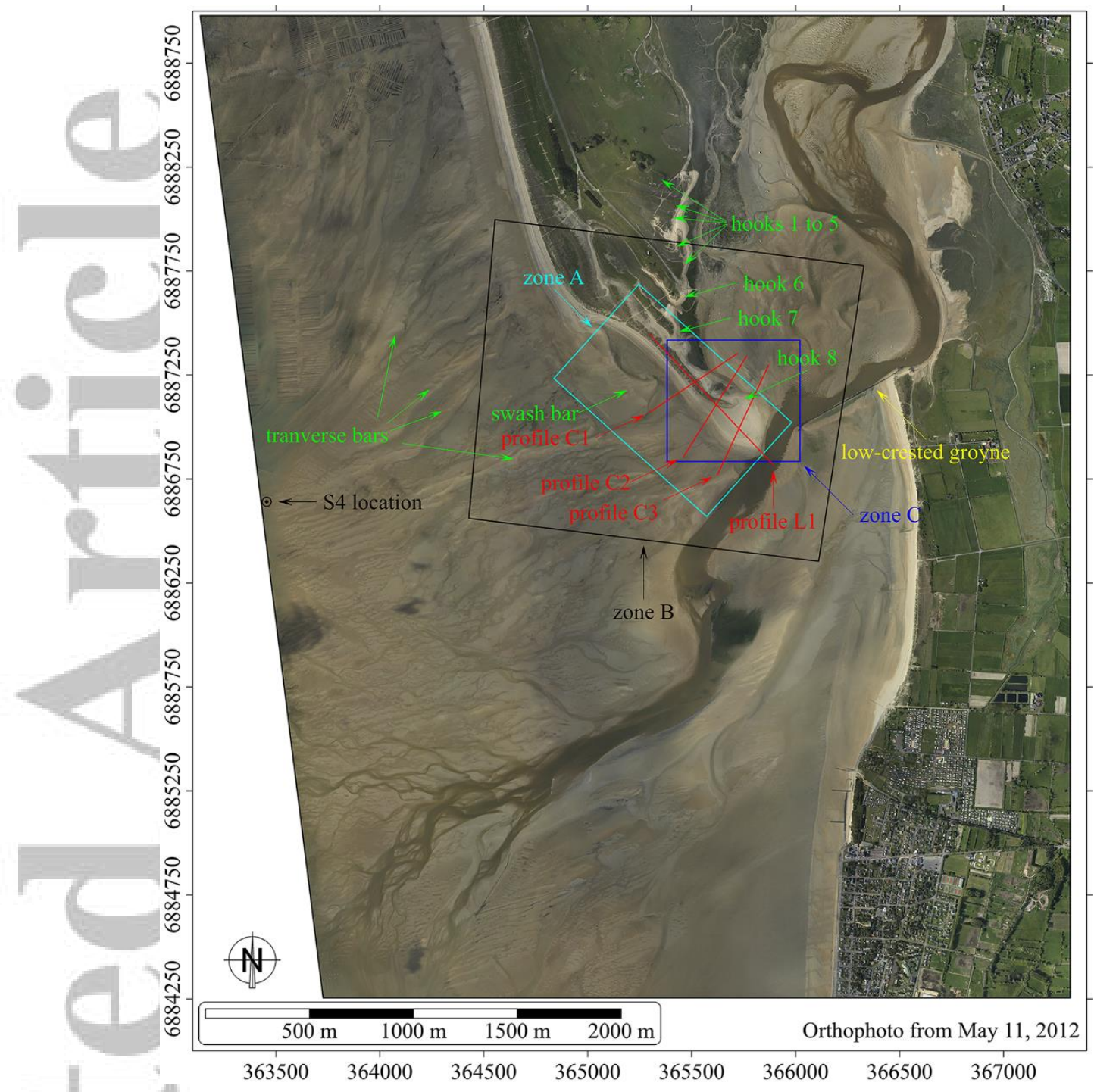

Fig. 2. Aerial photograph of Regnéville inlet showing several well-developed hooks at the distal tip of Agon spit. Location of each topographic clip (zone A: Fig.5; zone B: Figs.6, 9, 11; zone C: Fig.12) and profiles (C1, C2, C3 (Fig., 7) and L1 (Fig., 8)). 


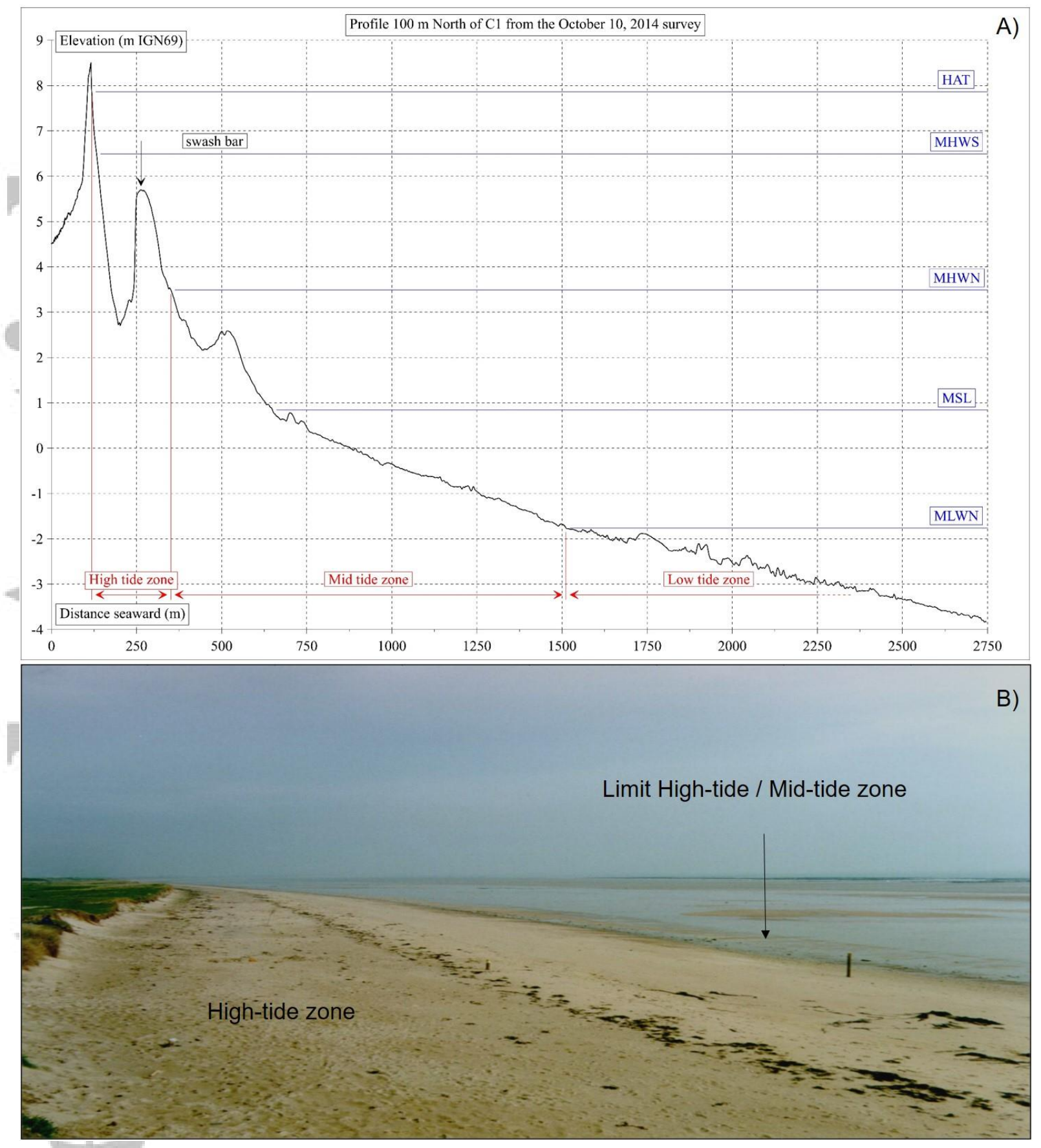

Fig. 3. (a) Typical transect of the supratidal and intertidal zones of the megatidal beach updrift of Regnéville inlet with horizontal lines indicating tidal levels (HAT, highest astronomical tide; MHWS, mean high water springs; MHWN, mean high water neaps; MSL, mean sea level; MLWN, mean low water neaps). (b) Ground photograph of the beach. 

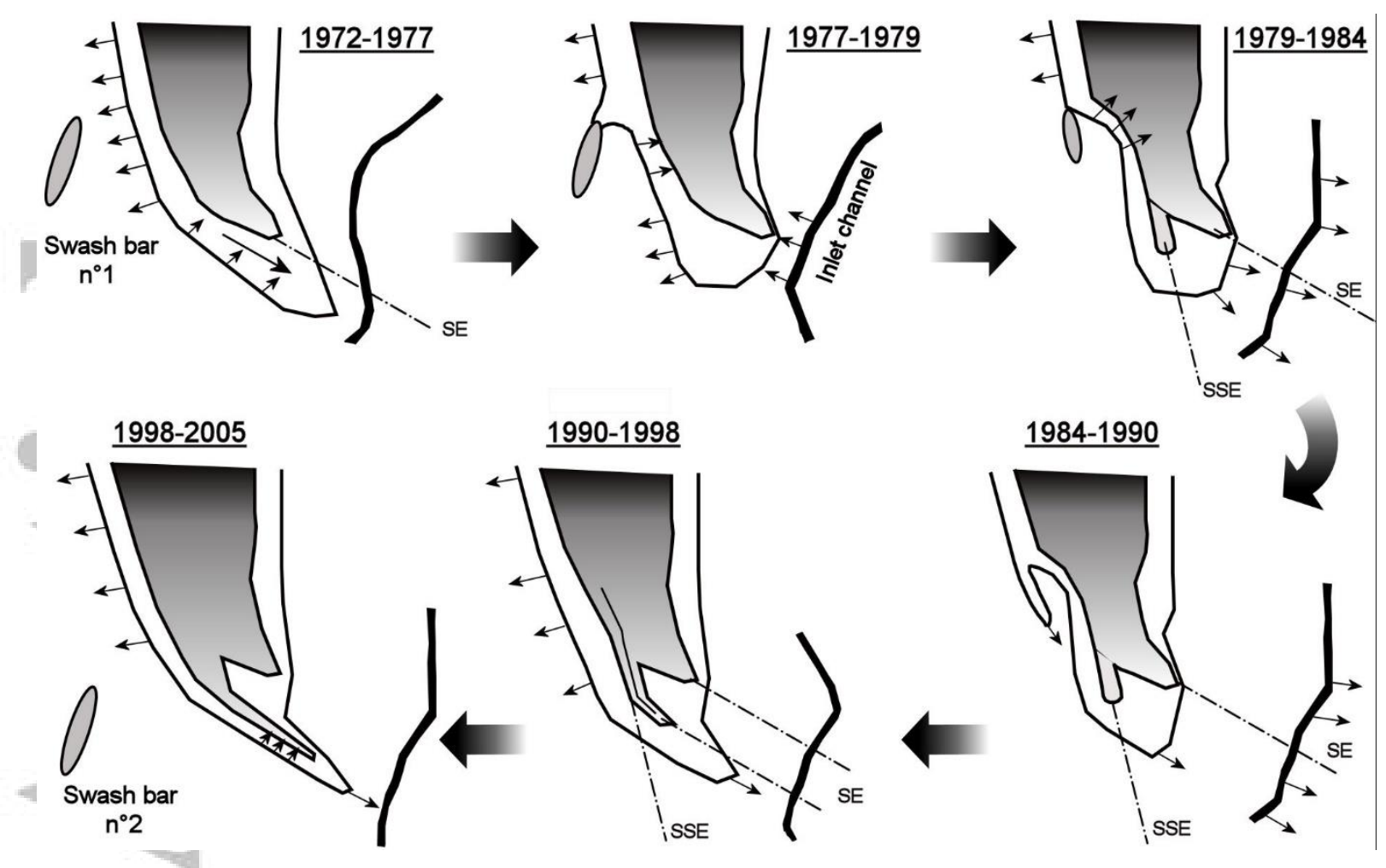

$\underline{1990-1998}$
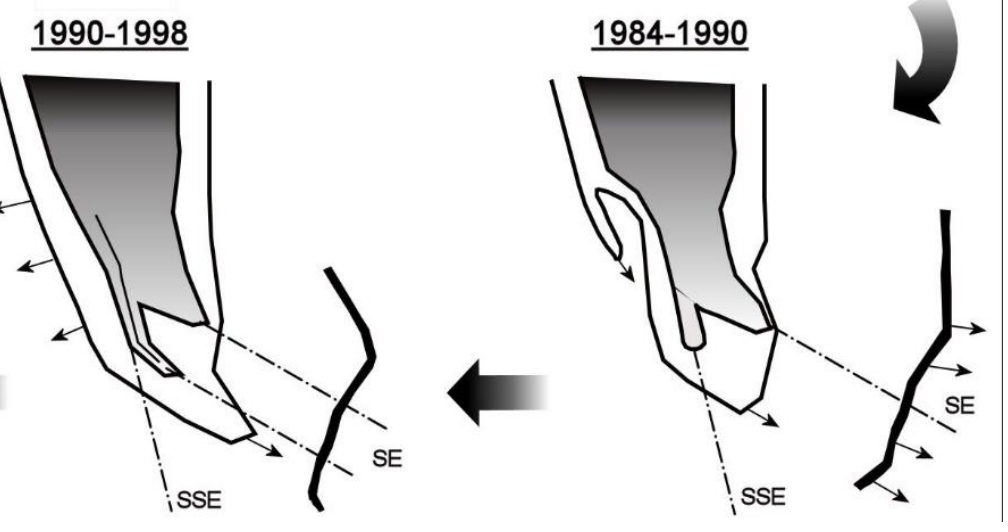

Fig. 4. Conceptual model of evolution of Agon spit showing the formation of a spit hook after migration and welding of a swash bar on the upper beach. Evolution tendency depicted by black arrows (from Robin and Levoy, 2007). 


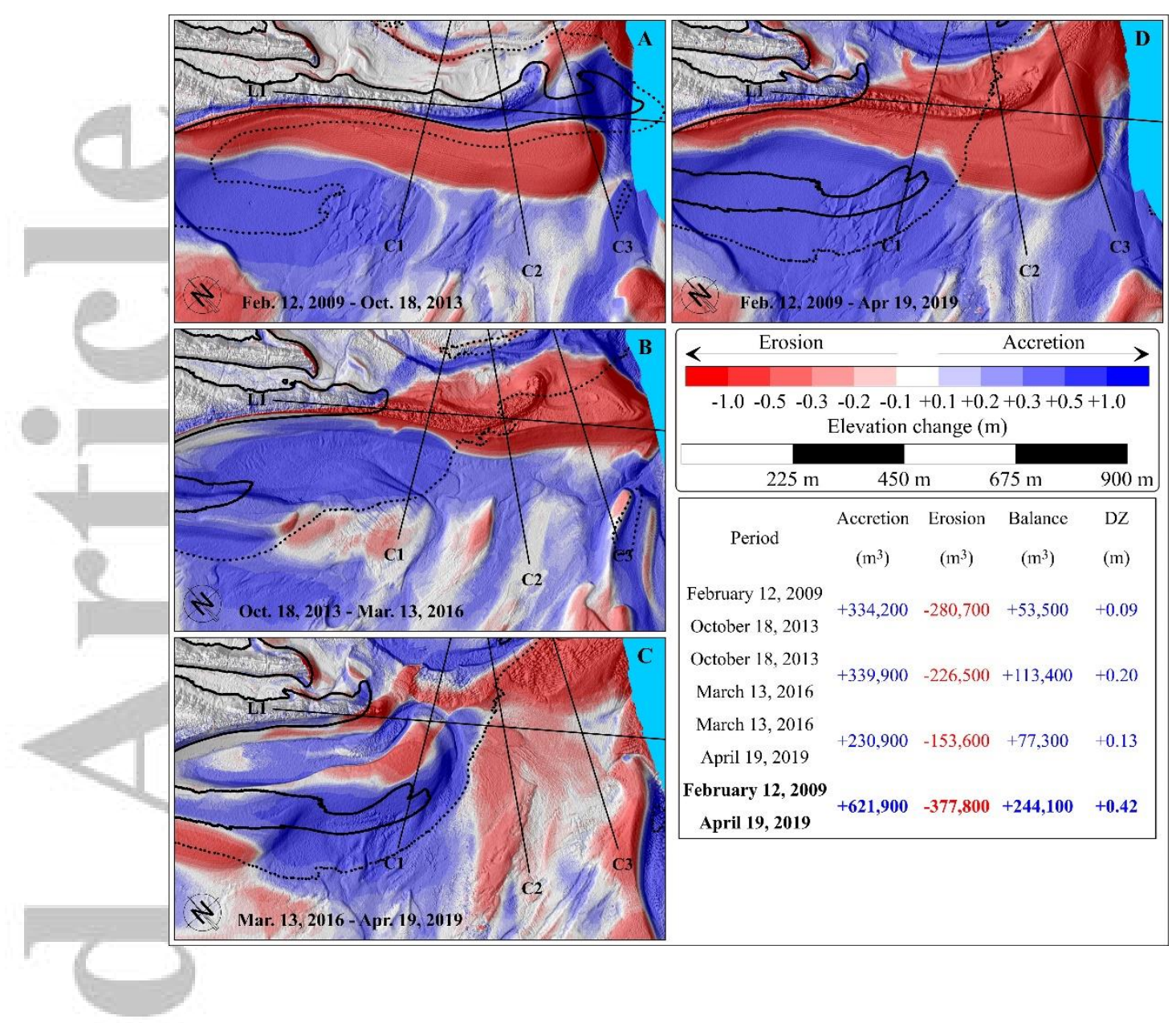

Fig. 5. Differential digital elevation models corresponding to three intervals between February 2009 and April 2019 (A, B, C) and residual morphological change (D). Black and dash lines correspond to MHWS and MHNS limits respectively. Topographic profiles are indicated. Table shows sand volume change for each of the intervals, and the total volume change over the 10-year period. 


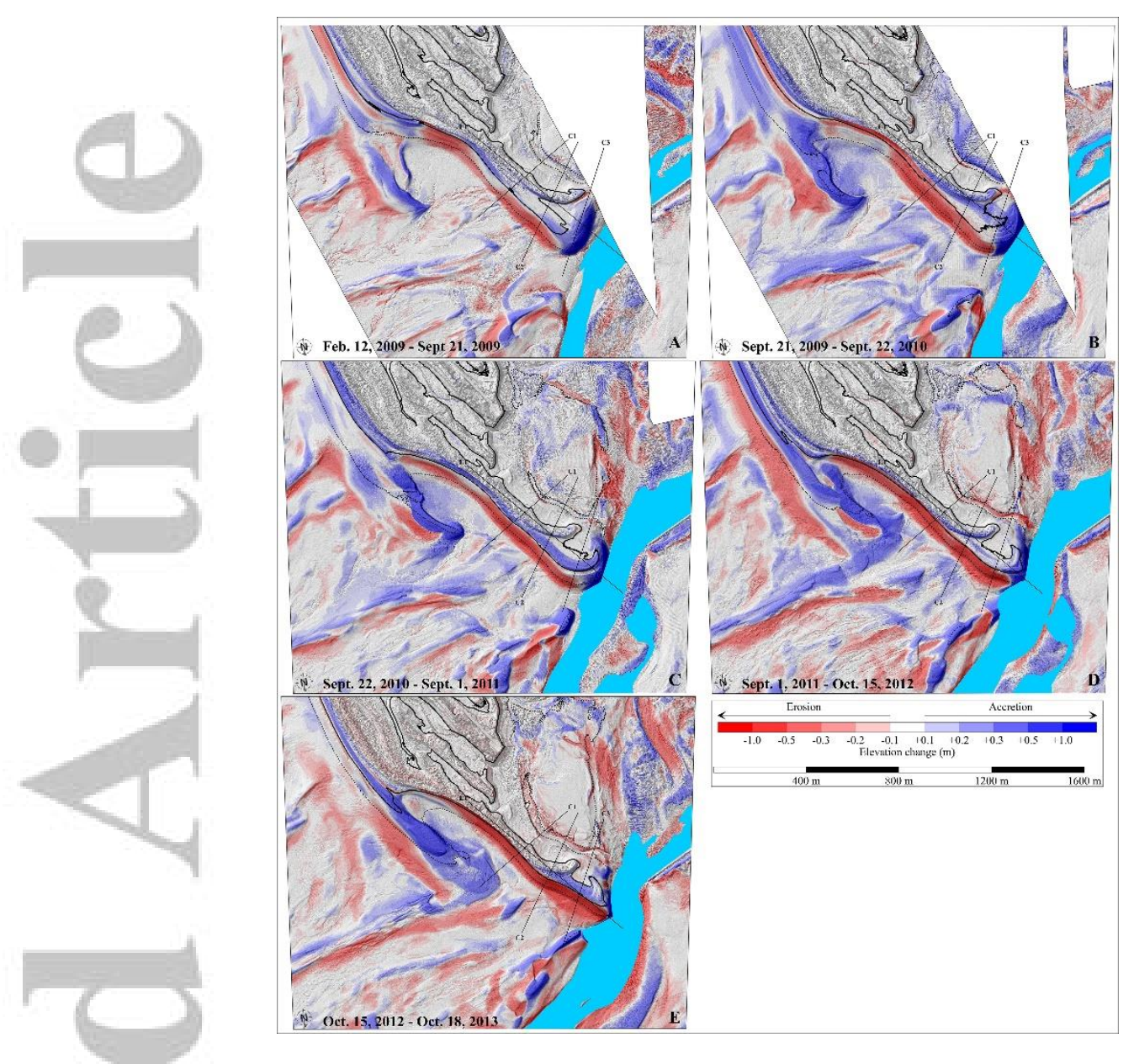

Fig. 6. Differential digital elevation models during the first morphological change stage (hook erosion, February 2009 to October 2013). Black and dash lines correspond to MHWS and MHNS limits respectively. Topographic profiles are indicated. 

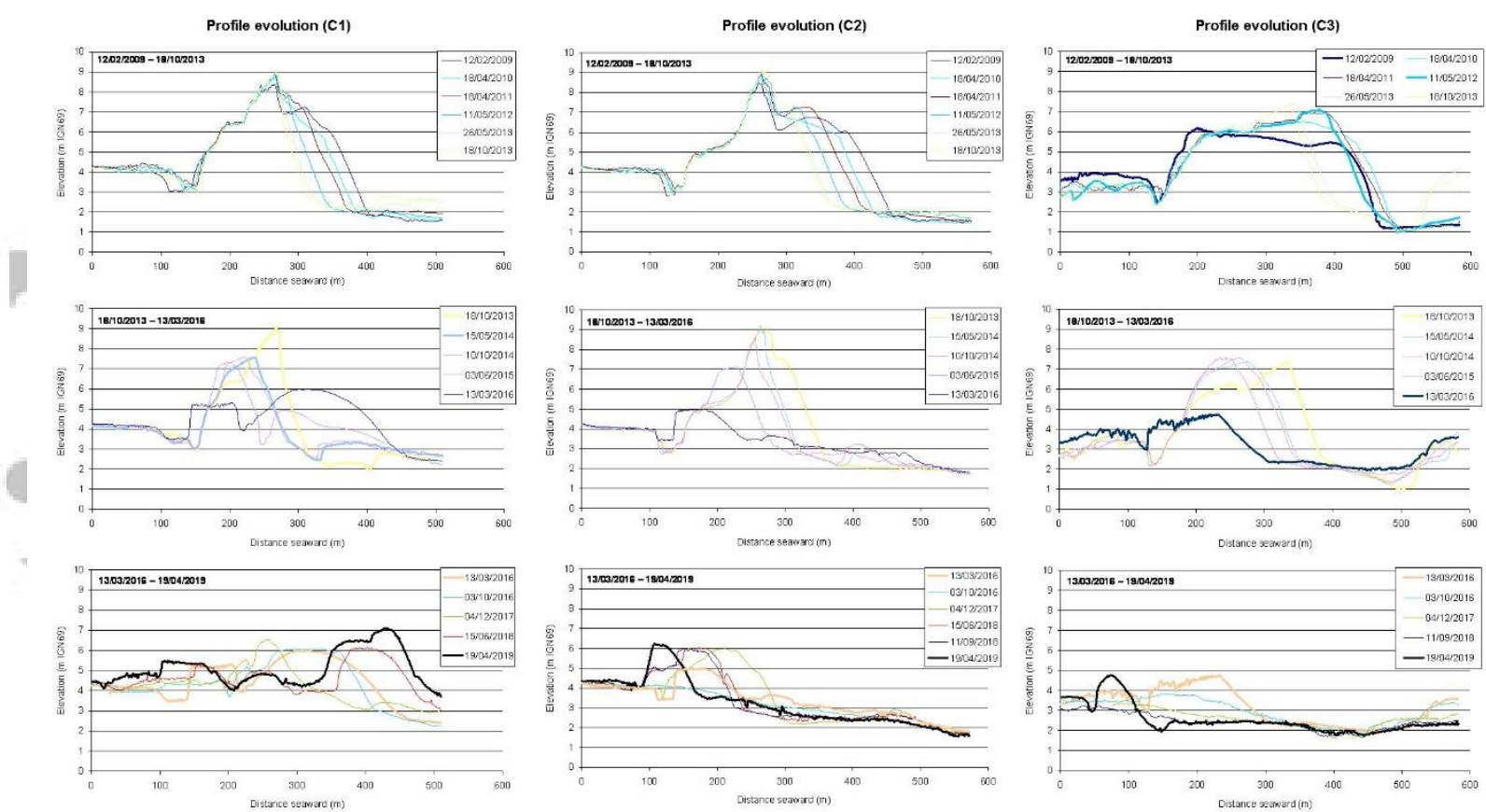

Fig. 7. Cross-shore profile evolution $(\mathrm{C} 1, \mathrm{C} 2, \mathrm{C} 3)$ during the three morphological change stages. 
Profile evolution (L1)
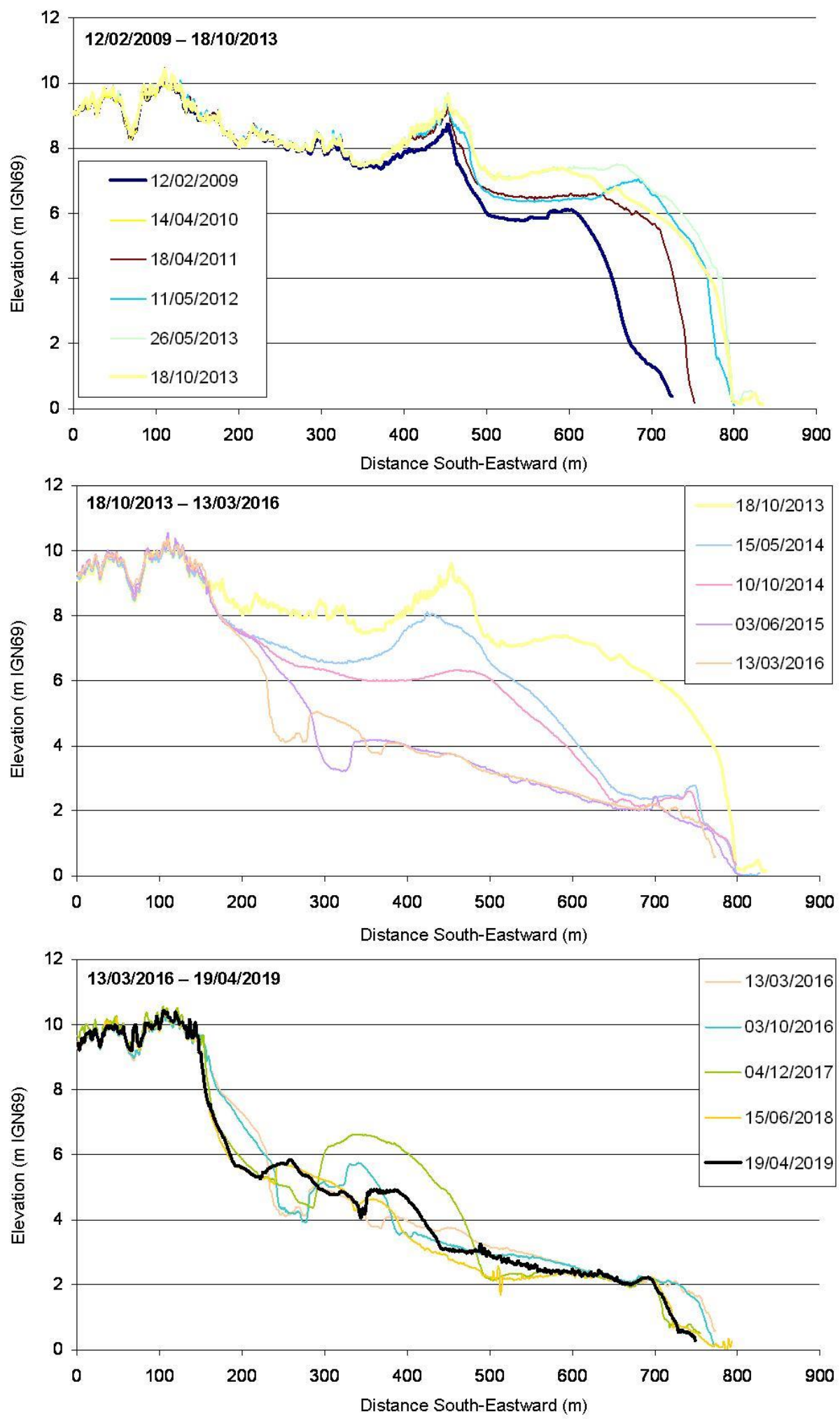

Fig. 8. Longshore profile evolution (L1) during the three morphological change stages.

This article is protected by copyright. All rights reserved. 


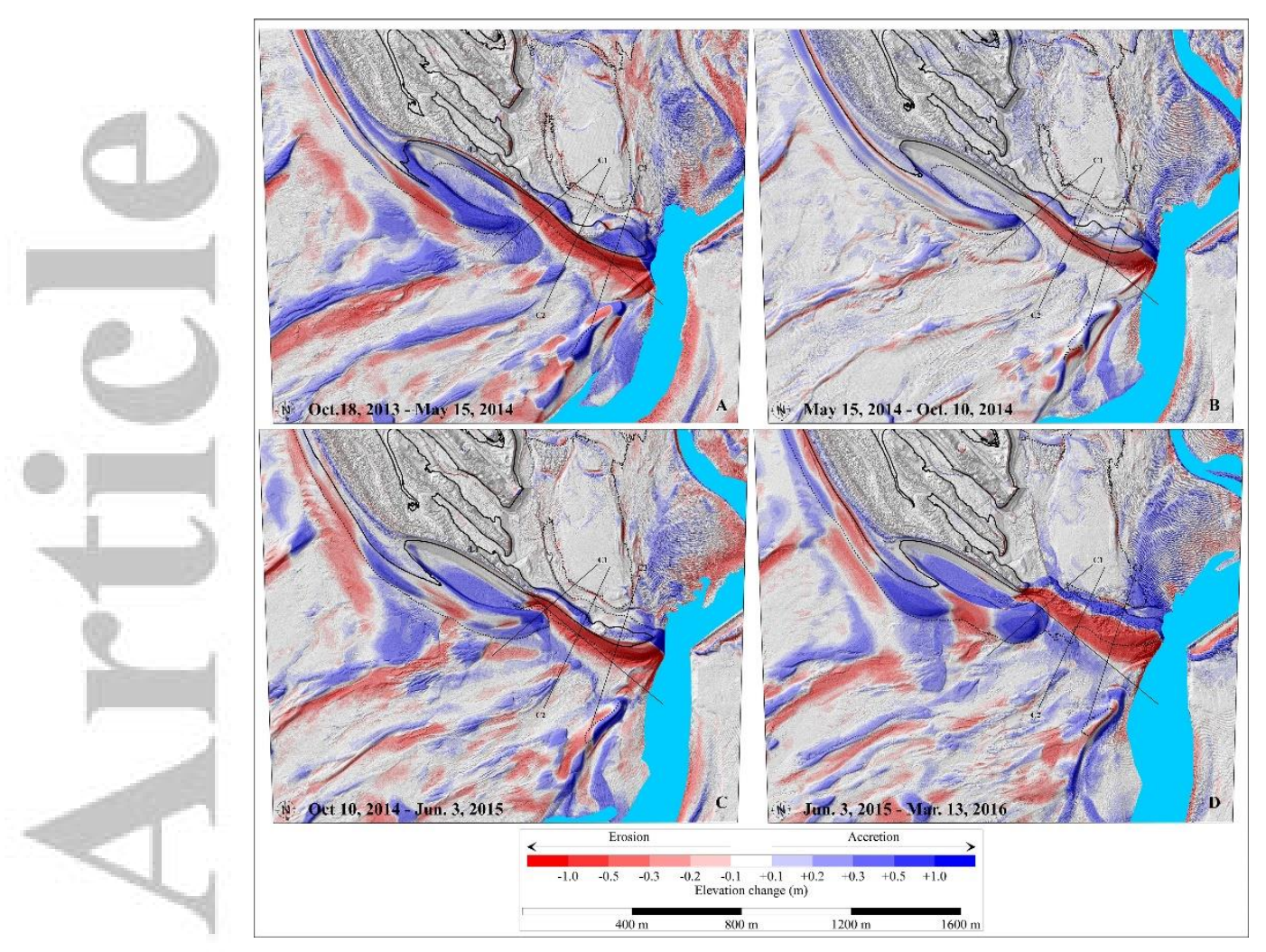

Fig. 9. Differential digital elevation models during the second morphological change stage (hook breaching and destruction, October 2013 to March 2016). Black and dash lines correspond to MHWS and MHNS limits respectively. Topographic profiles are indicated. 

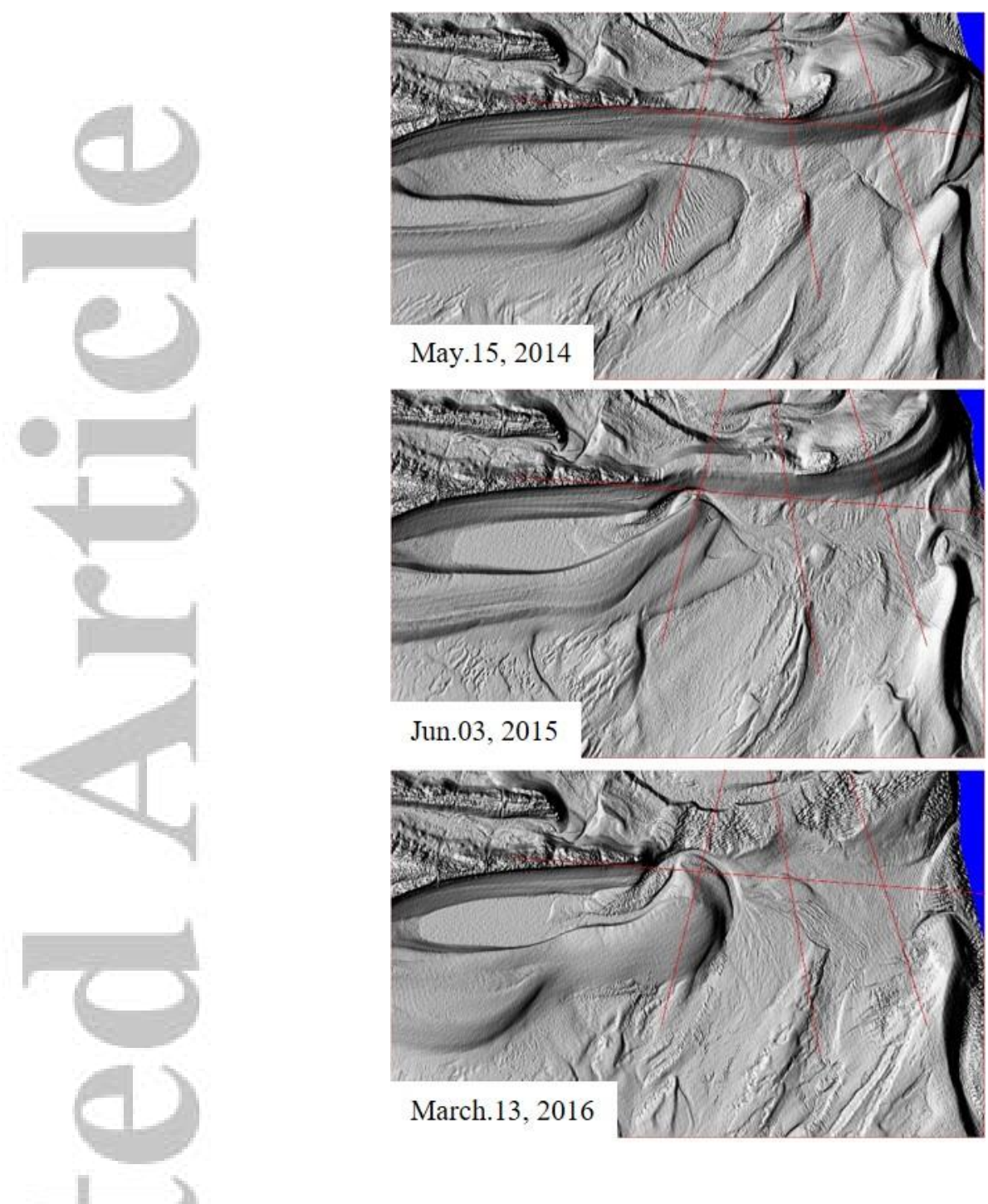

Fig. 10. Zoom on washover deposits and impact of the longshore evolution of the swash bar on the hook's distal tip. 

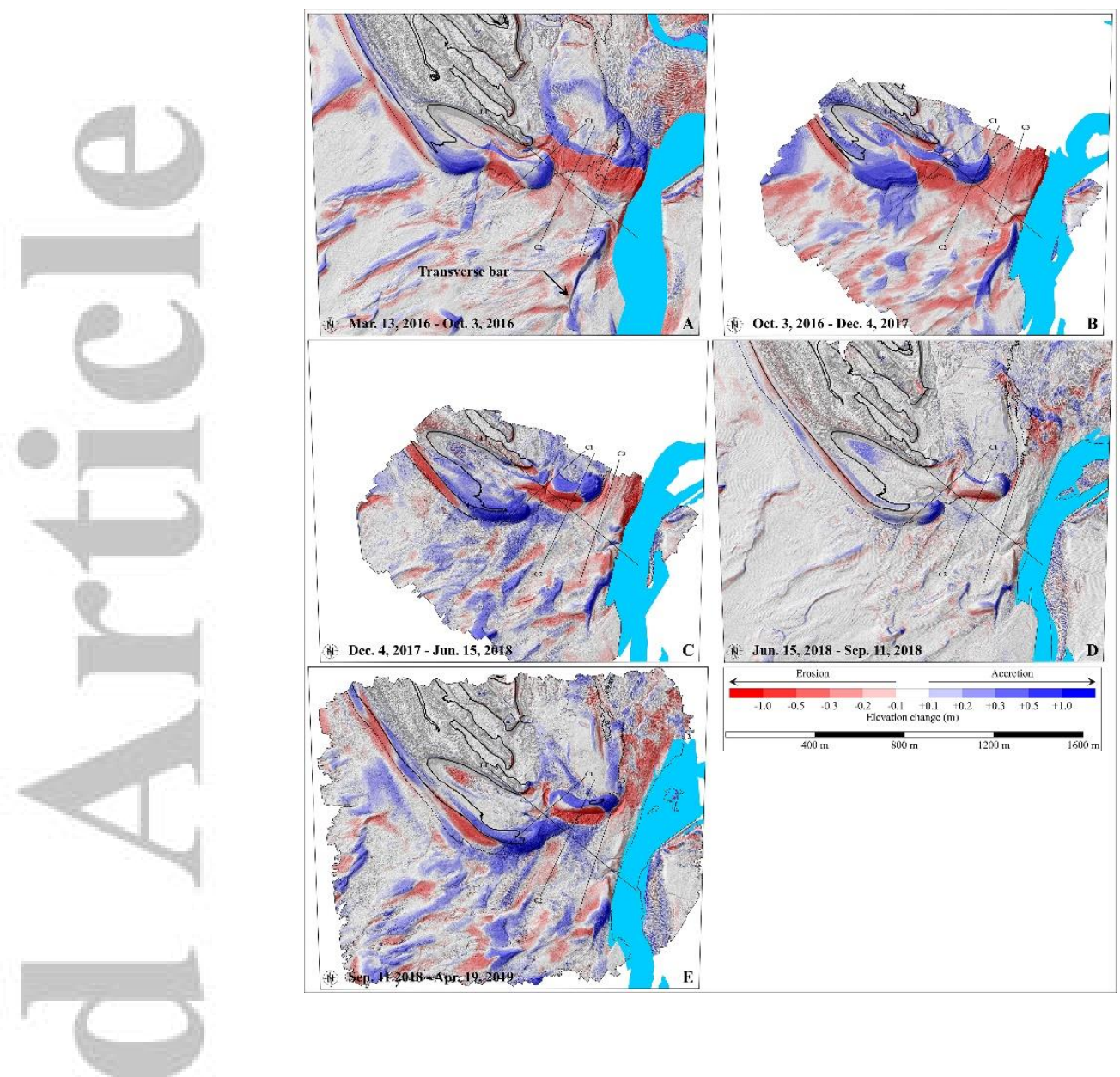

Fig. 11. Differential digital elevation models during the third morphological change stage (hook formation, March 2016 to April 2019). Black and dash lines correspond to MHWS and MHNS limits respectively. Topographic profiles are indicated.

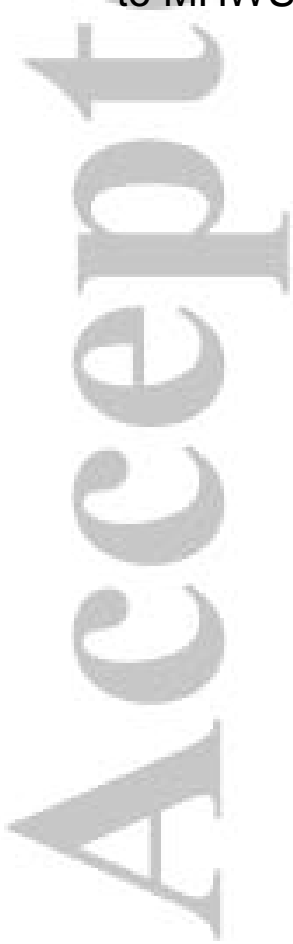

This article is protected by copyright. All rights reserved. 


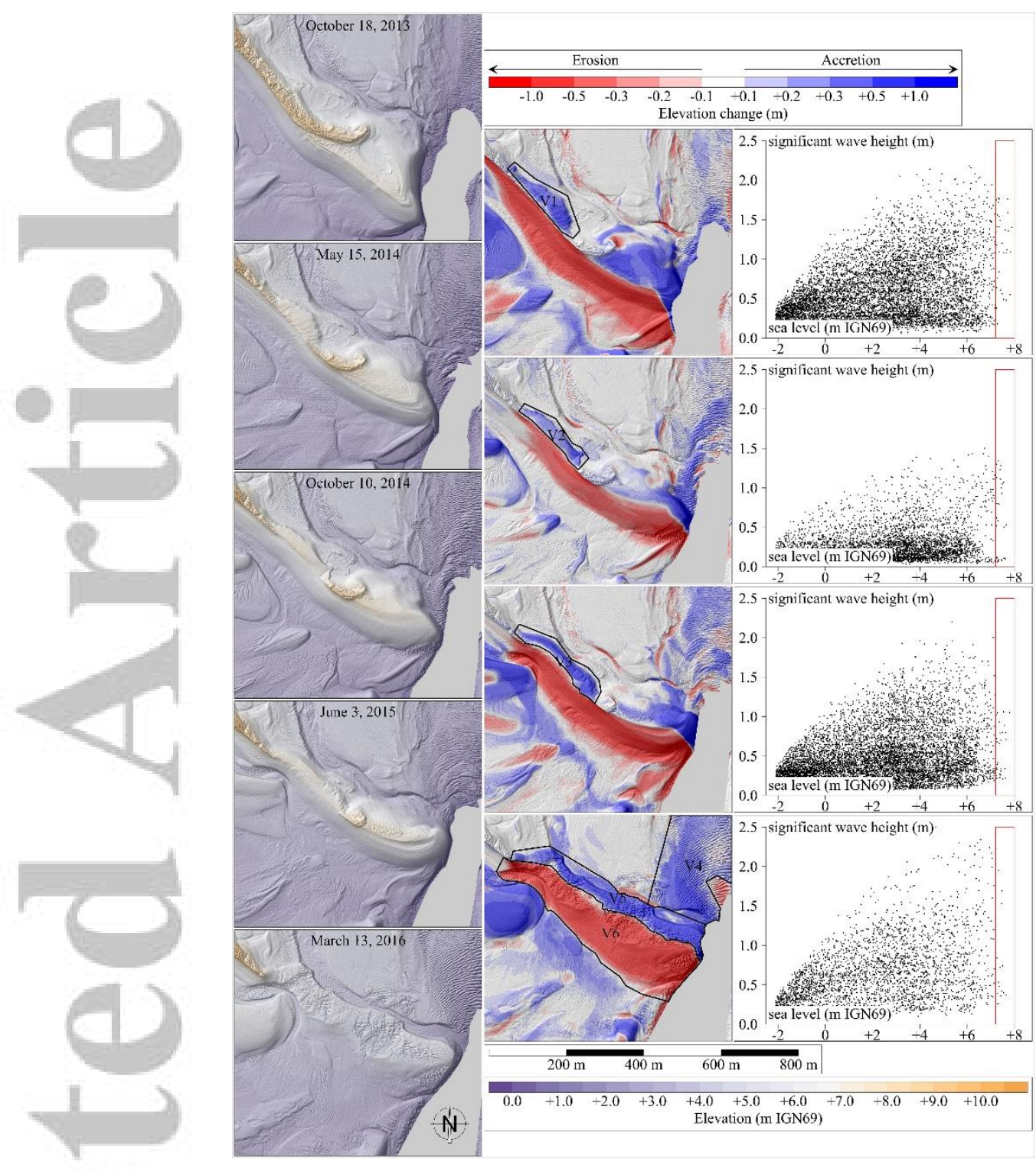

Fig. 12. Topographic changes following overwash events and the relationship between significant wave height and sea level (each dot corresponds to an interval of $1 \mathrm{~h}$ ). The duration of storms, combined with water levels $>7.3 \mathrm{~m}$ IGN69 (elevation of the dune crest) point to a relatively short interval for the production of such important morphological changes. 


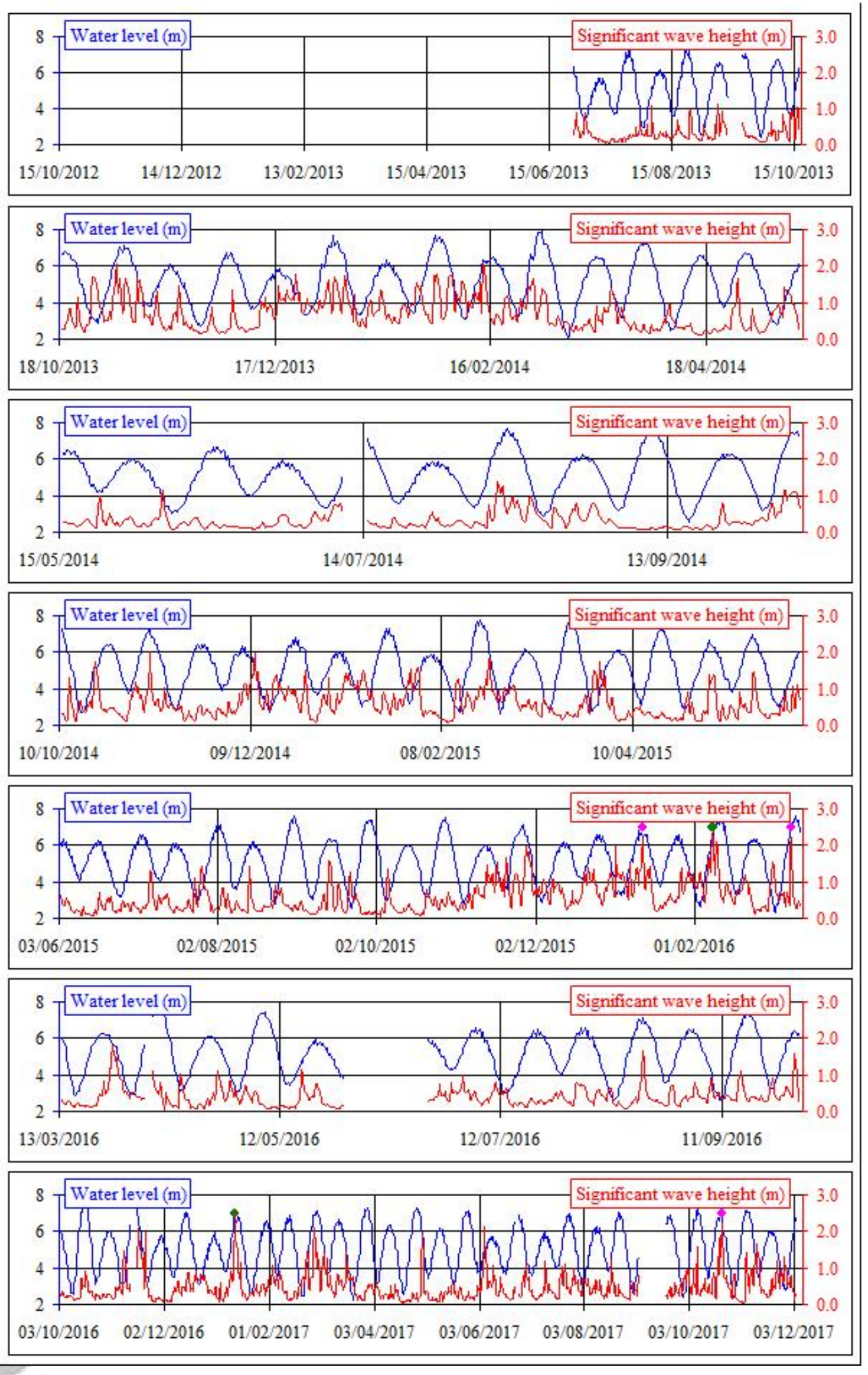

Fig. 13. Hydrodynamic conditions at high tide (water levels and significant wave heights) recorded between April 2012 and October 2017. Each graph corresponds to the intervals depicted in Figs., 6, 9 and 11. Green points correspond to sea level $>=6$ $\mathrm{m}$ and significant wave height $>=2.25 \mathrm{~m}$, pink points to sea level $>=6 \mathrm{~m}$ and significant wave height $>=2.12 \mathrm{~m}$ and $<2.25 \mathrm{~m}$. 


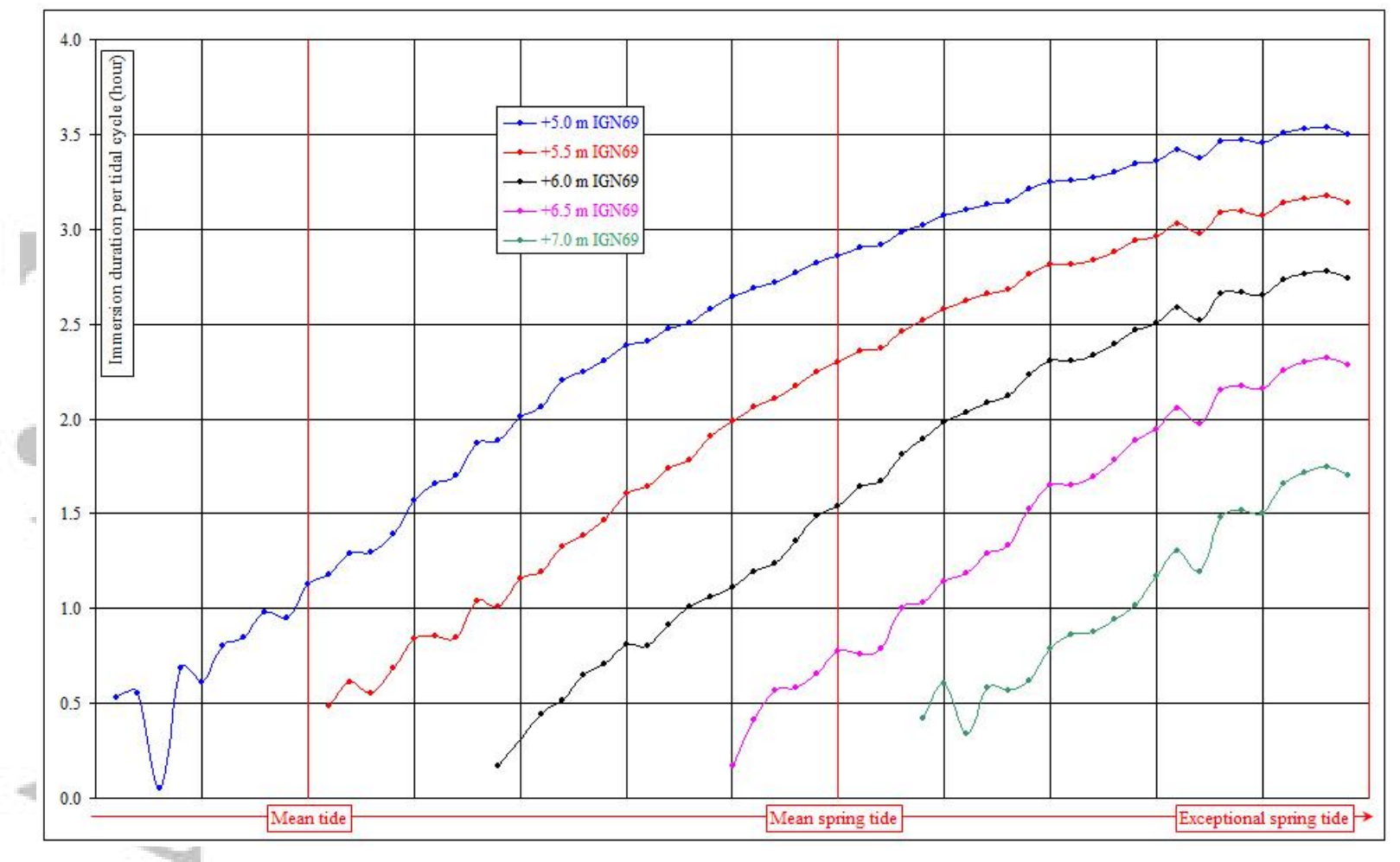

Fig. 14. Immersion duration per tidal cycle for several elevations of the beach, in relation to the tidal range. 

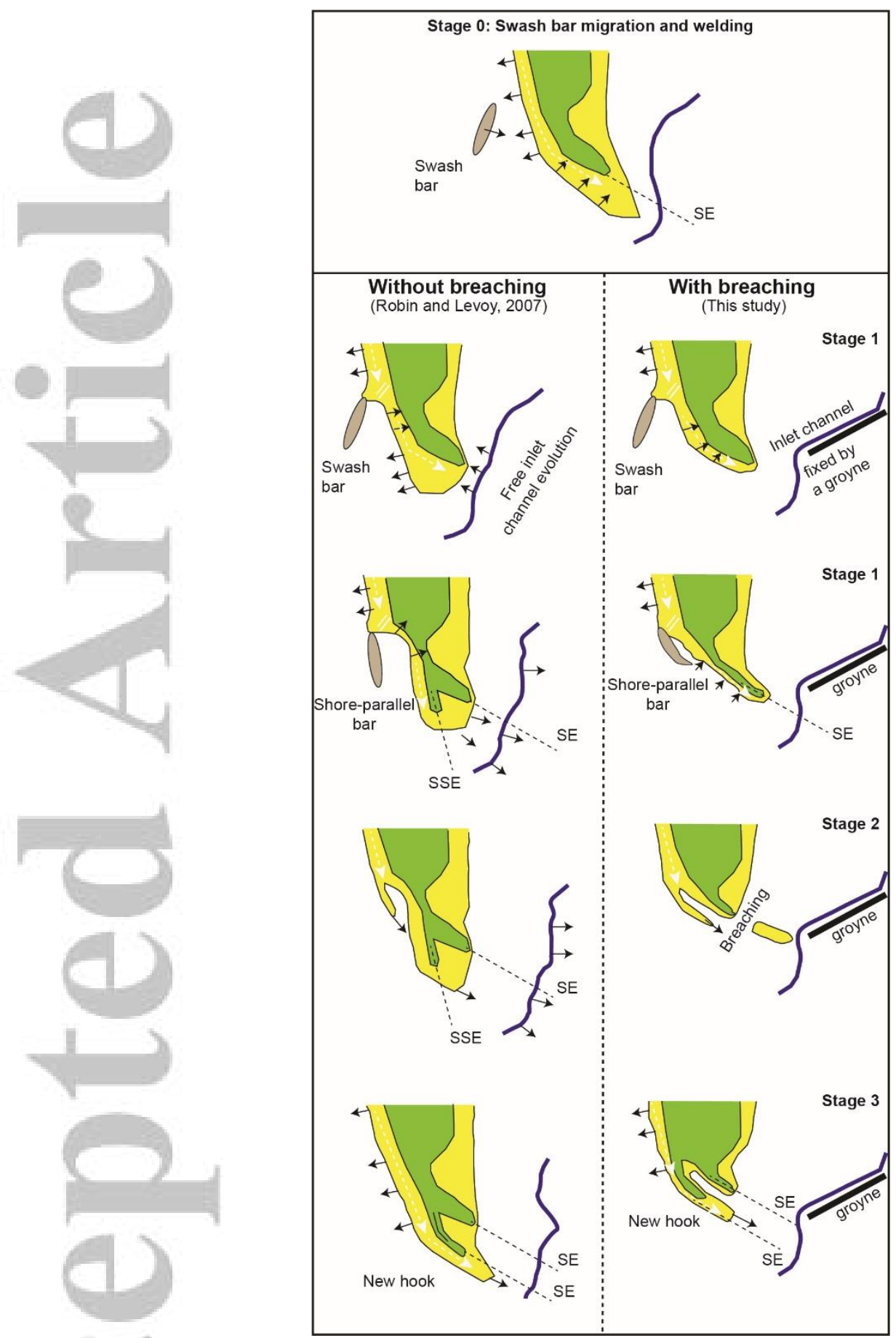

Figure 15. Conceptual model of evolution of the macrotidal hooked Agon spit derived from a dense ten-year dataset of LiDAR and UAV surveys between 2009 and 2019, and a comparson with the earlier model of Robin and Levoy (2007) based on 18 aerial photographs between 1947 and 2002. Evolution tendency depicted by black arrows. 
Table 1. Dates of topographic surveys.

\begin{tabular}{|l|l|l|}
\hline Survey number & Date of survey & Source \\
\hline 1 & February 12,2009 & CLAREC project \\
\hline 2 & September 21,2009 & CLAREC project \\
\hline 3 & April 18,2010 & CLAREC project \\
\hline 4 & September 22,2010 & CLAREC project \\
\hline 5 & April 18,2011 & CLAREC project \\
\hline 6 & August 31,2011 & CLAREC project \\
\hline 7 & May 12,2012 & CLAREC project \\
\hline 8 & October 15,2012 & CLAREC project \\
\hline 9 & May 26,2013 & CLAREC project \\
\hline 10 & May 15,2014 & CLAREC project \\
\hline 11 & June 3,2015 & CLAREC project \\
\hline 12 & March 13,2016 & CLAREC project \\
\hline 13 & October 3,2016 & CLAREC project \\
\hline 14 & May 9,2017 & CLAREC project \\
\hline 15 & December 4,2017 & UBECUS project \\
\hline 16 & June 15,2018 & UBECUS project \\
\hline 17 & September 11,2018 & COZULIT project \\
\hline 18 & April 19,2019 & UBECUS project \\
\hline
\end{tabular}


Table 2. Volumes of sediment mobilized during overwash events. Locations of zones are shown in Fig. 12.

\begin{tabular}{|c|c|c|c|c|c|c|}
\hline Period & Zone & $\begin{array}{c}\text { Accretion } \\
\text { volume }\end{array}$ & $\begin{array}{c}\text { Erosion } \\
\text { volume }\end{array}$ & Net volume & Surface & $\mathrm{DZ}$ \\
\hline $\begin{array}{c}\text { October, 18 2013 } \\
\text { May 15, 2014 }\end{array}$ & $\mathrm{V} 1$ & $+5830 \mathrm{~m}^{3}$ & $-10 \mathrm{~m}^{3}$ & $+5820 \mathrm{~m}^{3}$ & $11650 \mathrm{~m}^{2}$ & $+0.50 \mathrm{~m}$ \\
\hline $\begin{array}{c}\text { May 15, 2014 } \\
\text { October 10, 2014 }\end{array}$ & $\mathrm{V} 2$ & $+2710 \mathrm{~m}^{3}$ & $-10 \mathrm{~m}^{3}$ & $+2700 \mathrm{~m}^{3}$ & $8220 \mathrm{~m}^{2}$ & $+0.33 \mathrm{~m}$ \\
\hline $\begin{array}{c}\text { October 10, 2014 } \\
\text { June 3, 2015 }\end{array}$ & $\mathrm{V} 3$ & $+6790 \mathrm{~m}^{3}$ & $-10 \mathrm{~m}^{3}$ & $+6780 \mathrm{~m}^{3}$ & $10950 \mathrm{~m}^{2}$ & $+0.62 \mathrm{~m}$ \\
\hline $\begin{array}{c}\text { June 3, 2015 } \\
\text { March 13, 2016 }\end{array}$ & $\mathrm{V} 4$ & $+21340 \mathrm{~m}^{3}$ & $-290 \mathrm{~m}^{3}$ & $+21060 \mathrm{~m}^{3}$ & $44580 \mathrm{~m}^{2}$ & $+0.47 \mathrm{~m}$ \\
\cline { 2 - 8 } & $\mathrm{V} 5$ & $+33160 \mathrm{~m}^{3}$ & $-20 \mathrm{~m}^{3}$ & $+33140 \mathrm{~m}^{3}$ & $29220 \mathrm{~m}^{2}$ & $+1.13 \mathrm{~m}$ \\
\hline
\end{tabular}

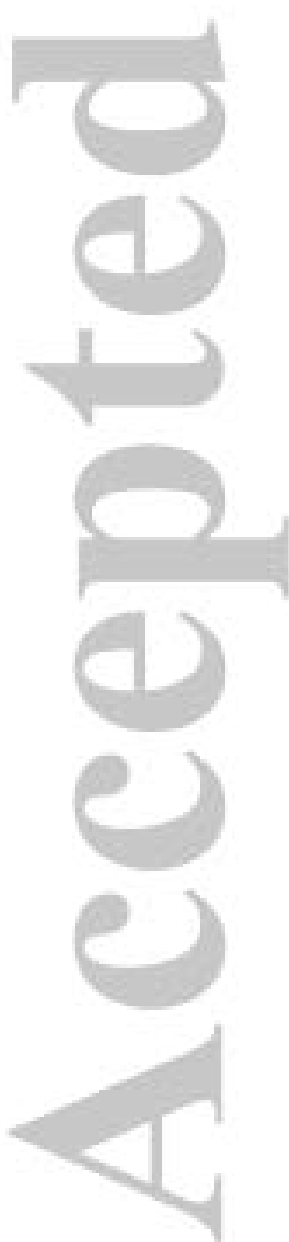

This article is protected by copyright. All rights reserved. 


\section{Graphical abstract}

Spits with distal hooks are well documented from coasts with low to moderate tidal ranges, unlike high tidal-range environments. Hydrodynamic, LiDAR and UAV surveys of a macrotidal spit show three stages of construction, destruction and reconstruction over ten years (2009-2019), with long phases of inertia punctuated by rapid change. Large tides actively control, together with waves and longshore currents, the dynamics and evolution of hooked sandy spits.

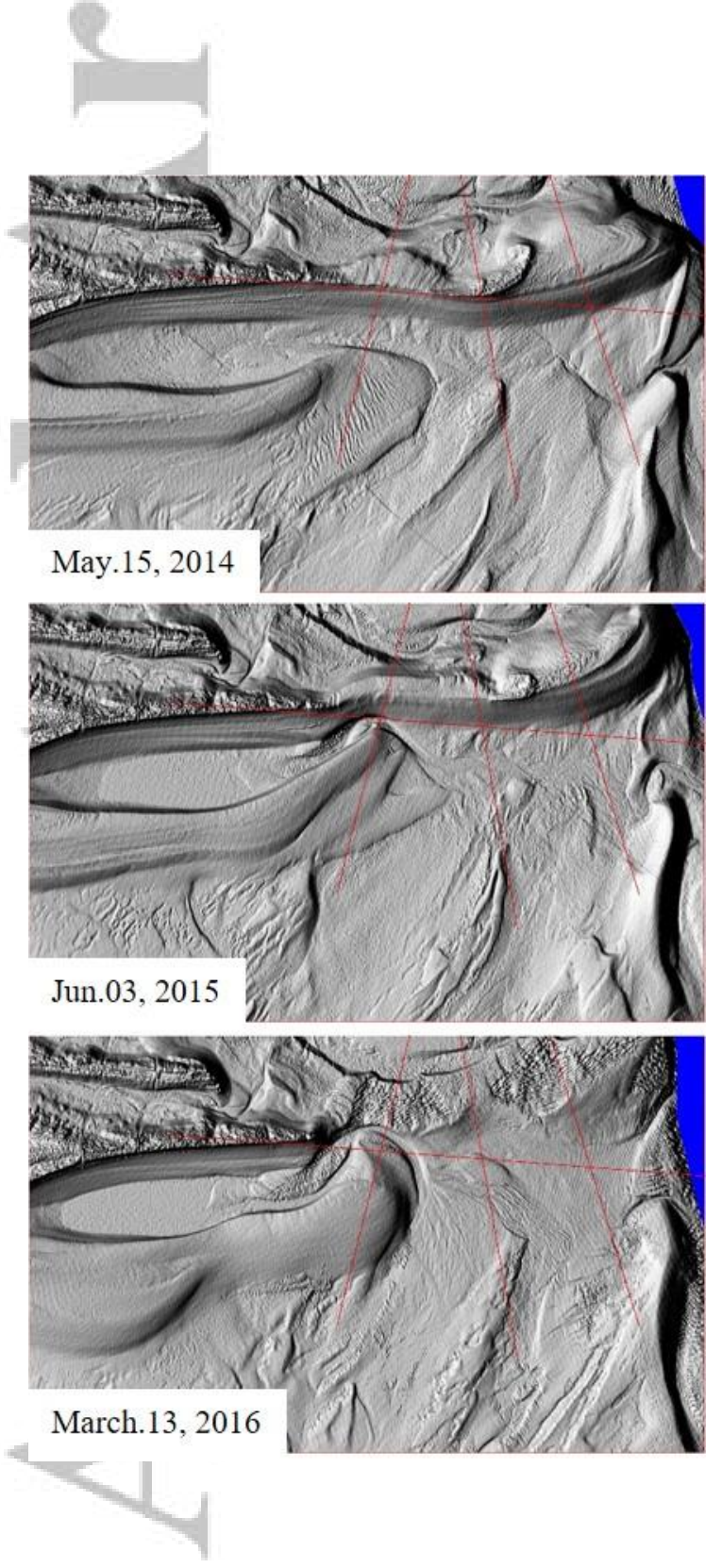

